\title{
Could ER Stress Be A Major Link Between Oxidative Stress And Autoimmunity In Vitiligo?
}

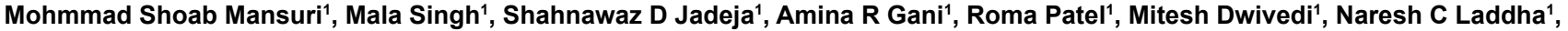 \\ Ansarullah², Ramachandran AV$^{2}$ and Rasheedunnisa Begum ${ }^{1 *}$ \\ ${ }^{1}$ Department of Biochemistry, Faculty of Science, The Maharaja Sayajirao University of Baroda, Vadodara, Gujarat -390002, India \\ ${ }^{2}$ Department of Zoology, Faculty of Science, The Maharaja Sayajirao University of Baroda, Vadodara, Gujarat -390002, India
}

\begin{abstract}
Vitiligo is an acquired pigmentary disorder characterized by areas of depigmented skin resulting from loss of epidermal melanocytes. The cause of the destruction of epidermal melanocytes is complex and not yet fully understood. However, there are several hypotheses related to biochemical, neural and genetic aspects as well as oxidative stress and autoimmune mechanisms proposed to understand this disorder. Oxidative stress has a role in vitiligo onset, while autoimmunity contributes to disease progression. In this review, we discuss the mechanisms that link triggering factors with the disease progression. Oxidative stress causes disruption in redox potentials that extend to the Endoplasmic Reticulum (ER), causing accumulation of misfolded proteins, which activates the Unfolded Protein Response (UPR). Melanocytes at the periphery of vitiligo lesions show dilation of the ER. Following exposure to various triggers of vitiligo melanocytes produce cytokines that activate immune response. These studies expand our understanding of the underlying mechanisms of melanocyte loss in vitiligo highlighting the possible mechanisms linking ER stress to oxidative stress and autoimmunity.
\end{abstract}

Keywords: Vitiligo; Oxidative stress; ER stress; Unfolded protein response; Auto immunity; Inflammation

Abbreviations: ROS: Reactive Oxygen Species; LPO: Lipid Peroxidation; ER: Endoplasmic Reticulum; UPR: Unfolded Protein Response; IRE1: Inositol-Requiring Enzyme-1; PERK: Protein Kinase RNA (PKR)-like ER Kinase; ATF6: Activating Transcription Factor-6; ERAD: ER-Associated Protein Degradation; BiP: Binding immunoglobulin Protein; eIF2 $\alpha$ : eukaryotic Initiation Factor $2 \alpha$; GPx: Glutathione Peroxidase; CHOP: CCAAT-Enhancer Binding Protein Homologous Protein; JNK: Janus Kinase; Hcy: Homocysteine; NSV: Non-Segmental Vitiligo

\section{Introduction}

Vitiligo is an acquired, hypomelanotic skin disease characterized by circumscribed depigmented macules on the skin due to melanocyte loss. The worldwide prevalence of vitiligo is $\sim 0.5-1 \%$ [1]. Vitiligo starts at the age of 20 years, in almost $50 \%$ of the patients and both males and females are affected [2-4]. Affected persons suffer from social and family stigma and, girls in particular, are subjected to ostracization from the marital point of view [5-9]. Vitiligo has been found to be associated with a number of other autoimmune diseases [10,11]. Vitiligo is a multifactorial polygenic disorder with a complex pathogenesis $[2,12-$ 15]. In vitiligo patients, skin melanocytes are partially or completely lost, and several theories have been put forward to explain the etiology of the disease such as oxidative stress, autoimmune, neural and genetic hypotheses $[2,12,16,17]$. Melanocyte death may occur due to intrinsic and/or extrinsic factors (Figure 1). Histological investigations have demonstrated presence of inflammatory infiltrate of mononuclear cells in the upper dermis and at the dermal-epidermal junction of peri-lesional skin of Non-Segmental Vitiligo (NSV) patients [18]. The initiation mechanism of this microinflammatory reaction is still not clear, nevertheless local triggers are reported to signal the innate immune system of skin that trigger adaptive immune responses targeting melanocytes $[19,20]$. There is wide range of evidence that show vitiligo to be a systemic rather than a local disorder. Impairment of humoral and cell-mediated immunity has been recognized in vitiligo patients $[17,21]$. Moreover, increased local and systemic cytokine expression has also been observed in vitiligo patients [22-31]. Many studies have addressed the key role of oxidative stress in melanocyte death and anti-melanocyte immune responses; however, the relationship between them remains unclear. Recently, we have reported a positive correlation between increased Lipid Peroxidation (LPO) levels and presence of circulating anti-melanocyte antibodies in vitiligo patients [32]. Reactive Oxygen Species (ROS) are produced as byproducts of melanogenesis controlled by various antioxidant enzymes [33-35]. Oxidative stress is considered to be the initial triggering event in the pathogenesis of melanocyte destruction [36]. Vitiligo is accompanied by oxidative stress characterized by overproduction and accumulation of $\mathrm{H}_{2} \mathrm{O}_{2}$ and melanocyte destruction [37-39]. For the interconnection between, oxidative stress and autoimmunity it has been suggested that oxidative stress may have a role in vitiligo onset, while autoimmunity contributes towards the disease progression [32,40]. Furthermore, Toosi et al. [41] demonstrated accumulation of misfolded proteins and activation of Unfolded Protein Response (UPR) in the endoplasmic reticulum due to redox disruptions caused by oxidative stress. Protein misfolding in the ER has been reported to contribute to the pathogenesis of many human diseases (Table 1). Though unfolded proteins have the potential to bring about ER homeostasis restoration and cell survival by the activation of Inositol-Requiring Enzyme-1 (IRE1), Protein Kinase RNA (PKR)-like ER kinase (PERK) and Activating Transcription Factor-6 (ATF6) pathways, persistent stress conditions can on the other hand trigger apoptosis [42-45] (Figure 2). Furthermore, inhibited UPR can contribute to the activation of autoimmune response by way of generation of self-altered antigens during degradation of misfolded proteins, besides release of neo-antigens by apoptotic cells, and altered immune-tolerance mechanisms in cells with an anomalous UPR [46].

These findings tend to suggest the possibility of a crosstalk between

${ }^{*}$ Corresponding author: Prof. Rasheedunnisa Begum, Department of Biochemistry, Faculty of Science, The Maharaja Sayajirao University of Baroda, Vadodara, Gujarat -390002, India, Tel: +91 265-2795594; E-mail: rasheedunnisab@yahoo.co.in

Received June 26, 2014; Accepted July 14, 2014; Published July 16, 2014

Citation: Mansuri MS, Singh M, Jadeja SD, Gani AR, Patel R, et al. (2014) Could ER Stress Be A Major Link Between Oxidative Stress And Autoimmunity In Vitiligo? Pigmentary Disorders 1: 123. doi:10.4172/2376-0427.1000123

Copyright: (c) 2014 Mansuri MS. This is an open-access article distributed under the terms of the Creative Commons Attribution License, which permits unrestricted use, distribution, and reproduction in any medium, provided the original author and source are credited. 


\begin{tabular}{|c|c|c|c|}
\hline Disease & Oxidative Stress & ER Stress & Autoimmunity \\
\hline Vitiligo & $\begin{array}{c}\text { Yes } \\
{[32,40,60]}\end{array}$ & $\begin{array}{c}\text { Yes } \\
{[72,108]}\end{array}$ & $\begin{array}{c}\text { Yes } \\
{[32,40]}\end{array}$ \\
\hline Type I Diabetes & $\begin{array}{c}\text { Yes } \\
{[256]}\end{array}$ & $\begin{array}{c}\text { Yes } \\
{[257]}\end{array}$ & $\begin{array}{c}\text { Yes } \\
{[258]}\end{array}$ \\
\hline Type II Diabetes & $\begin{array}{c}\text { Yes } \\
{[259]}\end{array}$ & $\begin{array}{c}\text { Yes } \\
{[260,261]}\end{array}$ & No \\
\hline Alzheimer's disease & $\begin{array}{c}\text { Yes } \\
{[262]}\end{array}$ & $\begin{array}{c}\text { Yes } \\
{[263,264]}\end{array}$ & No \\
\hline Parkinson's & $\begin{array}{c}\text { Yes } \\
\text { Disease }\end{array}$ & $\begin{array}{c}\text { Yes } \\
{[265,266]}\end{array}$ & No \\
\hline Cancer & $\begin{array}{c}\text { Yes } \\
{[269]}\end{array}$ & $\begin{array}{c}\text { Yes } \\
{[270,271]}\end{array}$ & No \\
\hline Arthrosclerosis & $\begin{array}{c}\text { Yes } \\
{[272]}\end{array}$ & $\begin{array}{c}\text { Yes } \\
{[273,274]}\end{array}$ & No \\
\hline Myocardial Infarction & $\begin{array}{c}\text { Yes } \\
{[275,276]}\end{array}$ & $\begin{array}{c}\text { Yes } \\
{[277]}\end{array}$ & No \\
\hline Heart Failure & $\begin{array}{c}\text { Yes } \\
{[278]}\end{array}$ & $\begin{array}{c}\text { Yes } \\
{[279]}\end{array}$ & No \\
\hline Inflammatory Bowel & Yes & Yes & Yes \\
Disease & {$[280]$} & {$[281]$} & {$[282]$} \\
\hline
\end{tabular}

Table 1: Involvement of oxidative stress, ER stress and autoimmunity in human diseases.

oxidative stress, ER stress and autoimmunity leading to melanocyte destruction in vitiligo patients. We review here possible mechanisms that can link triggering factors (such as ER stress) with disease progression (oxidative stress and autoimmunity) (Figure 1).

\section{Oxidative Stress in Vitiligo}

Oxidative stress is a consequence of imbalance between pro and antioxidant activities in cells. Reactive intermediates formed by oxidative stress damage cellular macromolecules like proteins, carbohydrates, DNA and lipids [34,35]. The accumulation of $\mathrm{H}_{2} \mathrm{O}_{2}$ in vitiligo patients disrupts the recycling of $(6 R)$-L-erythro-5,6,7,8tetrahydrobiopterin $\left(6 \mathrm{BH}_{4}\right)$ due to deactivation of $4 \mathrm{a}-\mathrm{OH}-\mathrm{BH}_{4}$ dehydratase. The characteristic fluorescence of the affected skin under Wood's lamp (UVA $351 \mathrm{~nm}$ ) is a property of 6- and 7-biopterin, $\mathrm{H}_{2} \mathrm{O}_{2}$ induced oxidation products. Rokos et al. [47] have reported accumulation of pterin-6-carboxylic acid (P-6-COOH) in the epidermis of vitiligo patients. They have also shown photo-oxidation of sepiapterin and 6-biopterin to P-6- $\mathrm{COOH}$ by UVA/UVB irradiation. Moreover, photolysis of sepiapterin and 6-biopterin produces $\mathrm{H}_{2} \mathrm{O}_{2}$ under aerobic conditions serving as an additional source for generation of $\mathrm{H}_{2} \mathrm{O}_{2}$ in vitiligo skin [47]. The aromatic amino acids L-phenylalanine, L-tyrosine and L-tryptophan are substrates for melanogenesis wherein $6 \mathrm{BH}_{4}$ is an essential electron donor in their hydroxylation. Apparently, $6 \mathrm{BH}_{4}^{4}$ is an essential component of the pigment generating system [48]. Elevated level of serum homocysteine reported in vitiligo patients [49] also seems interesting as oxidation of homocysteine can also generate ROS. Further, Reactive Nitrogen Species (RNS) also can be a contributing factor as inducible nitric oxide synthase activity in vitiligo epidermis is shown to be elevated, generating both $\mathrm{H}_{2} \mathrm{O}_{2}$ and peroxynitrite [50] (Figure 1). The activity of $\mathrm{H}_{2} \mathrm{O}_{2}$ metabolizing enzymes has been found to be altered both systemically and locally in vitiligo patients $[33,51]$. Furthermore, Methylene Tetrahydrofolate Reductase (MTHFR) which is involved in Hcy metabolism, affects ROS generation and the apoptosis process via downregulation of antioxidant enzymes such as glutathione peroxidase 1 (GPx1) [52,53]. Recently, Chen et al. [54] have suggested that an increased risk of vitiligo was associated with higher levels of total Homocysteine (tHcy) indicating the possible involvement of MTHFR and Hcy in pathogenesis of vitiligo [55]. SOD is a group of metallo-enzymes that scavenge and dismutate superoxide $\left(\mathrm{O}_{2}^{-}\right)$anion in its detoxification process resulting in the formation of $\mathrm{O}_{2}{ }^{-}$and $\mathrm{H}_{2} \mathrm{O}_{2}$ [56]. Increased SOD levels have been reported in vitiliginous and non-vitiliginous skin from vitiligo patients [57]. Our recent study has also shown significantly higher activity of all three isoforms of SOD i.e. SOD1, SOD2 and SOD3 in vitiligo patients [58]. Other reports have also shown increased SOD activity in whole blood and serum $[59,60]$ as well as peripheral mononuclear cells [61] from vitiligo patients. In addition, we have reported increased transcript levels of SOD2 and SOD3 in vitiligo patients suggestive of their increased activity in patients [58]. Another antioxidant enzyme GPx converts $\mathrm{H}_{2} \mathrm{O}_{2}$ and other peroxides into $\mathrm{H}_{2} \mathrm{O}$ protecting important cellular proteins and membranes from the potential damaging effect of ROS and LPO [62]. Earlier studies had revealed decreased GPx activity in plasma and skin biopsy samples of vitiligo patients [51,63]. Hazneci et al. [64] have shown lower levels of GPx in the epidermis of lesional and non-lesional skin from vitiligo patients. Moreover, Maresca et al. [33] have reported higher levels of GPx during vitiligo progression indicating an imbalance of antioxidants in the epidermis of vitiligo patients. Our previous studies have shown decreased erythrocyte GPx activity in patients with vitiligo $[60,65]$. Recently, we have found positive genotype-phenotype correlations for the two exonic polymorphisms of GPX1 with its decreased activity. Furthermore, we have also found decreased catalase and G6PD activities in vitiligo patients $[12,60,65]$ resulting into increased $\mathrm{H}_{2} \mathrm{O}_{2}$ accumulation. Moreover, Hasse et al. [66] have reported that accumulation of millimolar concentrations of $\mathrm{H}_{2} \mathrm{O}_{2}$ can affect antioxidant enzymes as proved by low blood catalase and GPx activity in vitiligo patients. Increased SOD and decreased catalase and GPx activities could be responsible for the accumulation of $\mathrm{H}_{2} \mathrm{O}_{2}$ which undergoes Fenton and/or Haber -Weiss reaction to produce produces hydroxyl radicals leading to lipid, protein and DNA damage [56]. High levels of epidermal $\mathrm{H}_{2} \mathrm{O}_{2}$ as well as the methionine oxidation product- methionine sulfoxide, have been demonstrated in vivo in vitiligo patients $[67,68]$. LPO is one of the hallmarks of oxidative stress. MDA (malondialdehyde) is an end product of lipid peroxidation, and elevated serum levels of MDA have been documented in patients with vitiligo $[56,60,69,70]$. Recently, we have also demonstrated increased MDA levels in vitiligo patients [32]. Moreover, the increased MDA levels were characteristic of active cases and early stage of onset of vitiligo suggesting the crucial role of oxidative stress in progression as well as initiation of the disease [32]. Ultrastructural changes suggestive of lipid peroxidation have been demonstrated in melanocytes, keratinocytes and Langerhans cells from the skin of patients with vitiligo, both in affected and peri-lesional areas [71-74]. Various studies indicate the importance of FOXO3a as a transcription activator of SOD2, catalase $(C A T)$, and peroxiredoxin 3 genes [75-77]. FOXO3a is a member of the forkhead class $\mathrm{O}$ (FOXO) transcription factors, and plays an important role in cell cycle regulation; apoptosis, oxidative stress, and DNA repair $[78,79]$. Olmos et al. [80] reported that FOXO3a can protect cells from oxidative stress by regulating SOD2 and CAT. In addition, FOXO3adeficient hematopoietic stem cells have shown reduced expression of ROS detoxification genes resulting in elevated levels of ROS [81]. Recently, Ozel Turkcu et al. [82] have shown decreased FOXO3a levels in vitiligo patients and its association with oxidative stress and active vitiligo suggesting its important role in oxidative stress mediated pathogenesis of vitiligo. Melanocytes are neural crest derived cells with an embryological link to the nervous system [83].

Neural hypothesis suggests that various neurochemical mediators including acetylcholine secreted by the nerve endings to be toxic to melanocytes leading to their destruction. Decreased acetylcholine esterase (AChE) activity has been shown in vitiliginous skin during 
depigmentation [84], suggesting that acetylcholine may aggravate the progression of vitiligo. In addition, decreased sweating in the depigmented epidermis of patients also suggests possible cholinergic involvement in vitiligo [85]. Moreover, Schallreuter et al. [86] have shown $\mathrm{H}_{2} \mathrm{O}_{2}$ mediated oxidation of AChE further emphasizing the role of oxidative stress in the precipitation of vitiligo. The inactivation of AChE has been proposed to be due to oxidation of Trp432, Trp435 and Met436 residues by $\mathrm{H}_{2} \mathrm{O}_{2}$ [86]. Acetylcholine has an inhibitory effect on melanocyte DOPA oxidase activity affecting melanin production [84]. Our previous studies have in fact shown decrease in blood AChE activity [87] and significant increase in lipid peroxidation levels in vitiligo patients $[32,40,60,65,87]$. These reports provide evidence for AChE inhibition in vitiligo patients to be due to high oxidative stress. Acetylcholine thus accumulated may lead to the destruction of melanocytes resulting in the precipitation of vitiligo.

The above literature review emphasizes the role of oxidative stress in the pathogenesis of vitiligo and indicates oxidative stress to be a more generalized course of action rather than a localized phenomenon. This could be one of the reasons for developing new lesions in vitiligo patients in the course of the disease [57]. Oxidative stress can also lead to the activation of stress signaling pathways and their transcription factors $[88,89]$. Even though the exact molecular mechanisms by which ROS activate these pathways are not understood, their activation can lead to different consequences, including growth arrest, senescence, upregulation of death proteins, and cell death by apoptosis or necrosis. Cells undergo apoptosis by cell surface, ER or mitochondrial pathways. In our earlier review, we had addressed the interplay between oxidative stress and immune system in vitiligo [40]. In the current review, we focus on structural and functional aberrations of ER linking oxidative stress with autoimmunity in vitiligo pathogenesis.

\section{ER Stress in Vitiligo}

In eukaryotic cells, the ER is crucial for synthesis, folding and maturation of proteins, lipid metabolism, and homeostasis of intracellular $\mathrm{Ca}^{2+}$ and redox potential. Previous studies of Schallreuter et al. $[90,91]$ have shown perturbed calcium homeostasis in vitiliginous melanocyte and keratinocyte cell cultures, suggesting altered ER functions in vitiligo. Protein folding and modifications in the ER are highly sensitive to disturbances in ER homeostasis involving glycosylation, ER $\mathrm{Ca}^{2+}$ store, mRNA translation, oxidative stress, energy deprivation, metabolic challenge, and inflammatory stimuli. The accumulation of unfolded and misfolded proteins in the ER lumen, termed ER stress, activates intracellular signaling pathways to resolve the protein folding defect. This UPR tends to increase the capacity of ER protein folding and modification by reducing global protein synthesis, and activating ER-Associated Protein Degradation (ERAD). If ER stress is too severe or chronic, or the UPR is compromised and not able to restore the protein-folding homeostasis, numerous apoptotic signaling pathways get activated [92-94]. Preclinical and clinical studies in the past decade indicate ER stress and UPR to have a significant impact in the pathogenesis of multiple human disorders including vitiligo (Table 1). The ER stress response involves 3 distinct mechanisms: (i) translational attenuation of global protein synthesis (ii) transcriptional activation of chaperone and ERAD genes and (iii) ERAD mediated translocation of misfolded or aggregated ER proteins to the cytoplasm for proteasomal degradation [95] (Figure 2). The activation of UPR is mediated by three distinct ER stress sensors: PERK, ATF6 and IRE1 [45]. In non-stressed cells, these sensors are retained in the ER lumen by interaction with $\mathrm{BiP} /$ glucose-related protein 78 (GRP78). During ER stress, these three sensors become free of $\mathrm{BiP}$, leading to the induction of the three stress response mechanism
[95]. The alteration in $\mathrm{ER} \mathrm{Ca}^{2+}$ homeostasis can result in the activation of cytosolic calpains. They play a major role in ER mediated apoptosis by processing and activating caspase- 12 and caspase- 4 [96,97]. Severe and/or prolonged ER stress generally result in apoptotic cell death. The pro-apoptotic transcription factor CCAAT-enhancer binding protein homologous protein $(\mathrm{CHOP})$ is strongly induced in response to $\mathrm{ER}$ stress [98] (Figure 2). Further, ROS cause protein damage leading to accumulation of misfolded proteins in the ER lumen. Many studies have shown $\mathrm{H}_{2} \mathrm{O}_{2}$ induced ER stress response factors cited above in different cells including human oral keratinocytes [99]. Apoptosis mediated by ER stress involves increased expression of CHOP, cleavage of calpastatin, and activation of calpain, caspase- 4 and -12 . Caspase- 4 cleavage and up-regulation of CHOP were shown to be induced by peroxide radical in human oral keratinocytes [99]. Exact mechanism(s) regulating ER stress mediated apoptosis is (are) not fully understood. Several different pathways have been implicated including the

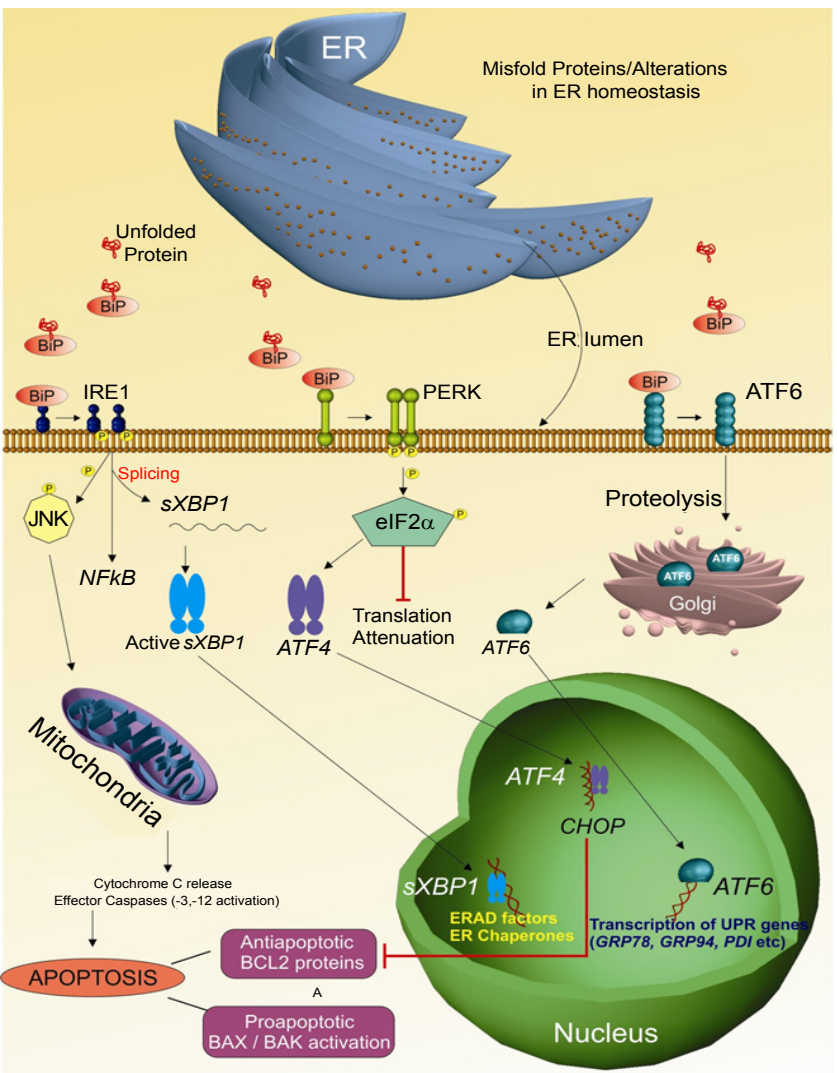

Figure 1: Overview of ER Stress Signaling Pathways: Activation of protective responses by UPR involves signal transduction through the IRE1, PERK and ATF pathways. PERK, IRE1, and ATF6 act as ER stress sensors by binding to the ER chaperone BiP, and by which they remain inactive under normal condition. Upon the accumulation of unfolded proteins, BiP preferentially binds to the unfolded proteins, which results in the release of PERK, IRE1, and ATF6. IRE1, once released from BiP, induces XBP1 by promoting the splicing of its $m R N A$. SXBP1 regulates chaperone induction and ERAD in response to ER stress. IRE1 also activates JNK which leads to cytochrome $C$ release from mitochondria and activation of effector caspases leading to apoptosis. The released PERK phosphorylates elF2 $\alpha$ to suppress the overall transcription of mRNAs while selectively enhances the transcription of genes implicated in UPR such as the ATF4 mRNA. ATF4 thus formed initiates the transcription of UPR target genes like CHOP which represses antiapoptotic BCL2 proteins and activated proapototic Bax/Bak leading to apoptosis. The release of ATF6 from BiP results in the translocation of ATF6 to the Golgi apparatus, where ATF6 is cleaved and then translocates into the nucleus, and initiates the transcription of target genes. 


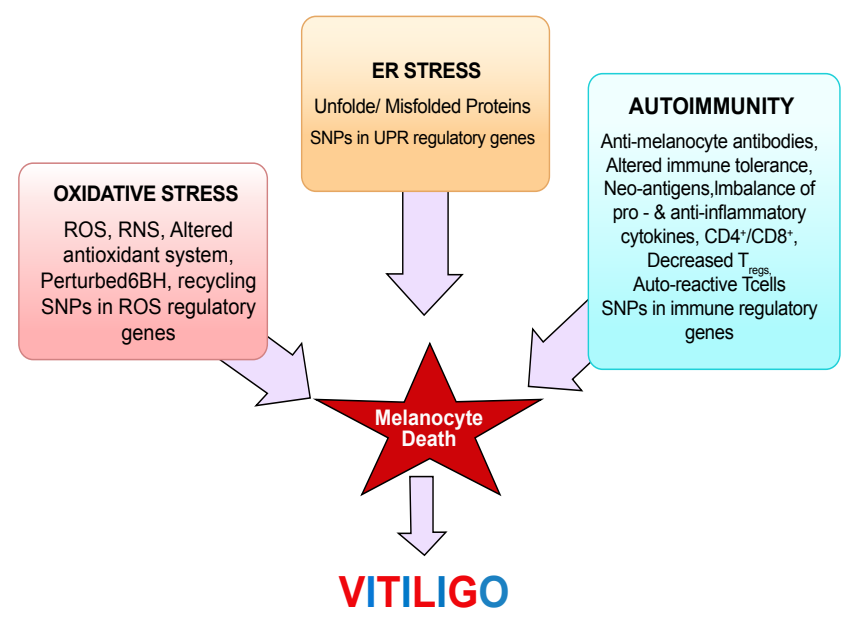

Figure 2: Multiple factors involved in melanocyte destruction leading to vitiligo: The factors such as ROS, RNS, UPR, auto-antibodies, auto-reactive T cells along with genetic susceptibility are involved in melanocyte destruction. A cumulative effect of oxidative stress, ER stress and autoimmune components is sought to be responsible for loss of melanocytes in vitiligo.

caspase-12/caspase-4, CHOP, or IRE1- JNK (Janus kinase) pathways [89]. Although caspases-12 and -4 have been implicated in ER stressinduced apoptosis, the events responsible for their activation remain ill defined. Pallepati and Averill-Bates [100] have shown $\mathrm{H}_{2} \mathrm{O}_{2}$ induced apoptosis in the ER of HeLa cells to be dependent on $\mathrm{Ca}^{2+}$, calpain and caspase-7. The role of caspase-12 in ERmediated apoptosis though well understood in mice [96], its role in human cells is nevertheless unclear as human caspase-12 gene carries many inactivating mutations [101]. However, caspase-12 activation has been detected in several human cell lines, including HeLa cells [102,103].

Dilation of melanocyte ER has been reported by different groups in perilesional skin biopsies as well as melanocytes cultured from vitiligo patients [72,104,105]. Moreover, Moellmann et al. [106] and Galardi et al. [107] have also reported ER damage in surrounding keratinocytes as well. The defect in the perilesional melanocyte ER has been substantiated in both in vivo and in vitro conditions [72]. Manga et al. [108] have in fact shown caspase-12 mediated apoptosis in wild type melanocytes by thapsigargin induced ER stress. Tyrosinase which is a rate-limiting enzyme in melanogenesis, undergoes post-translational modifications, including N-linked glycosylation [109], and disulfide bond dependent folding [110] in the ER to attain a functional tertiary structure [111]. Such post-translational modifications require classical ER chaperones [110] in addition to melanocyte-specific factors [112]. Tyrosinase misfolding and retention can be a consequenece of either mutations in chaperone genes [tyrosinase-related protein 1 (TRP1) [113], oculocutaneous albinism type 2 gene (OCA2) [114] and OCA4 [115] or tyrosinase gene itself [116]. Toosi et al. [41] in their investigations involving early events associated with induction of vitiligo by 4-tertiary butyl phenol (4-TBP) and Monobenzyl Ether of Hydroquinone $(\mathrm{MBEH})$ have shown ER stress in human melanocytes. They have also shown increased expression of $X B P 1$, after exposure of melanocytes to phenols. Interestingly, they observed increased production of IL6 and IL8 upon XBP1 activation in their studies on induced vitiligo suggesting cytokine production by melanocytes linking to an activation of immune response. Ren et al. [117] have shown both increased expression of $X B P 1$ in the lesional skin of vitiligo patients and association of XBP1 polymorphisms with increased risk of developing vitiligo. Oxidative stress induced ER dysfunction may involve non-functional thioredoxin domain containing 5 (TXNDC5) chaperone protein that has a protein disulphide isomerase-like domain to bring about protein folding. Three exonic SNPs of TXNDC5 and their susceptible haplotypes were found to be significantly associated with vitiligo [118]. Earlier report indicates localization of both pro- and anti-apoptotic members of the BCL2 family in ER and together they regulate homeostasis and cell death in response to signals that impact ER function [119]. These proteins function at the potential point of integration between IRE1 and CHOP mediated apoptosis. Abdel-Aal et al. [120] have shown decreased $B C L 2$ expression in lesional, peri-lesional and nonlesional vitiliginous skin as well as increased expression of $p 53$ in the lesional skin from vitiligo patients. These findings emphasize increased susceptibility of melanocytes to apoptosis in the vitiliginous skin.

\section{Autoimmunity in Vitiligo}

Case reports on inflammatory vitiligo furnished the first hint for the involvement of $\mathrm{T}$ cells in the pathogenesis of vitiligo [121-123]. Immune-mediated responses are consistently observed in progressive vitiligo at the periphery of depigmenting patches. Histopathological investigations of the peri-lesional skin suggest lymphocyte involvement in the depigmentation process. Immunohistochemical studies have also confirmed the presence of infiltrating $\mathrm{T}$ cells and their frequent opposition to peri-lesional melanocytes in skin biopsies from vitiligo patients $[124,125]$. Notably, similar in situ $\mathrm{T}$ cell infiltrates, primarily $\mathrm{CD}^{+} \mathrm{T}$ cells, have also been detected in generalized vitiligo [126-131]. T cells are more prevalent in vitiligo peri-lesional skin than in surrounding non-lesional skin. The lymphocyte infilterate consists essentially of $\mathrm{CD}^{+} \mathrm{T}$ cells with occasional $\mathrm{CD}^{+} \mathrm{T}$ cells [124]. The prevalence of cytotoxic $\mathrm{T}$ cells and their co-localization with surviving melanocytes suggest $\mathrm{T}$ cell mediated cytotoxicity towards the melanocytes [132]. Various other studies including ours show decrease in systemic CD4 ${ }^{+}$ $\mathrm{T}$-cells and an increase in $\mathrm{CD}^{+} \mathrm{T}$-cells with consequent decrease in $\mathrm{CD}^{+} / \mathrm{CD}^{+}$ratio in vitiligo patients, suggesting role of $\mathrm{CD}^{+}$cells in melanocyte death [133-136]. Recently, studies have shown a defective functionality and decreased frequency of regulatory $\mathrm{T}$ cells (Tregs) in vitiligo patients suggestive of the unchecked activation of $\mathrm{CD}^{+}$cells $[136,137]$. Furthermore, Bertolotti et al. [131] have also reported the presence of IFNa secreting plasmacytoid dendritic cells (pDC) in the infilterate of progressive vitiligo. IFN $\alpha$ induces the expression of $M x A$, which encodes a guanosine triphosphate (GTP)-metabolizing protein. Association of MxA with the expression of chemokine (C-X-C motif) ligand 9 [CXCL9] correlates well with the recruitment of chemokine (C-X-C motif) receptor $3^{+}\left[\mathrm{CXCR}^{+}\right]$immune cells. Further, they also showed increased expression of $M x A$ in peri-lesional skin in close opposition to surviving melanocytes within the T-cell infiltrate. In contrast, MxA was not evident in lesional skin, suggesting that IFN $\alpha$ production is an early event in the progression of the disease. Autoimmune aspect of vitiligo pathogenesis is strongly supported by the presence of auto-reactive T-cells $[17,124,138]$.

They target melanocyte-specific antigens, such as melan-A/MART1, Gp100/Pmel 17 (a melanosomal matrix glycoprotein), tyrosinase [139-141], TRP1 and TRP2 [132,142] that are localized primarily on melanosomes [143-145]. In fact auto-antibodies against melanocyte antigens have been detected in the sera of vitiligo patients $[10,32,146]$. The transcription factors SOX9 and SOX10 have also been identified as melanocyte auto antigens [147]. Even auto antibodies against HLA Class I molecules have been detected in vitiligo [138]. A positive correlation has been seen between the level of melanocyte antibodies and disease progression in vitiligo [148]. This is further supported by the concentration of these antibodies in proportion to extent of skin lesion [149]. Overall, all these point to a new innate immune pathway 
leading to the progression of vitiligo. Genes within class II region of the major histocompatibility complex (MHC) are associated with several autoimmune diseases [150]. This highly polymorphic region includes several genes involved in the processing and presentation of antigens to the immune system including low molecular weight polypeptide 2 and 7 (LMP2 and LMP7) and transporter associated with antigen processing 1and 2 (TAP1 and TAP2). Though $L M P / T A P$ gene cluster is located on MHC class II region of chromosome 6, it is involved in antigen presenting function of MHC class I molecule. Different researchers have reported association of $L M P 7$ and TAP1 with vitiligo susceptibility [151]. LMP2 and LMP7 are also involved in the degradation of ubiquitin tagged cytoplasmic proteins to peptides while, TAP1 and TAP2 are involved in transportation of peptides into the endoplasmic reticulum for exposure to nascent MHC class I molecules [150]. MHC-I molecules are crucial in the regulation of cytotoxic effector functions of Natural Killer (NK) cells and T cells. MHC-I molecules present antigens to cytotoxic $\mathrm{T}$ cells and are part of the recognition signals that regulate activation of NK cells [152]. Usually, antigenic peptides are generated by proteasomal degradation of cytosolic proteins and consequently translocated to ER by TAP. In the ER, assembly of MHC class I a chain, $\beta 2$-microglobulin and peptides is guided by chaperones [150]. On the other hand antigenic peptides are associated with the chaperones GRP94, GP96, PDI and calreticulin [153-156]. Functional class I-peptide complexes are then transported to the cell surface. A necessary condition for the successful completion of this complex process is glycosylation and correct folding of MHC class 1 heavy chain in the ER. A failure in the above results in their slow or inefficient transport to the cell surface [157161]. ER stress may result in decreased expression of MHC class I on the cell surface, thereby preventing the recognition of cells by the adaptive and innate immune system $[162,163]$. It has been reported that defects in the expression of different components of the MHC class I antigen processing machinery, such as the proteasomal subunits LMP2 and LMP7 and the peptide transporters TAP1 and TAP2, account for impaired MHC class I surface expression [151]. Further, an inappropriate expression or functioning of LMP7 might inhibit antigen processing and presentation, leading to a loss of peripheral tolerance to self-antigens and occurrence of several autoimmune diseases [151]. In this context, Ulianich et al. [152] have shown ER stress induced decrease in surface expression of MHC class I in thyroid cells. This effect was accompanied by activation of NK cells and their cytotoxicity to thyroid cells by increased IFN $\gamma$ production. Together, these data indicate ER stress induced reduction in MHC class I expression and reduced NK-cells self-tolerance. It has been shown that IFN $\gamma$ induces LMP and TAP subunits [151]. Our previous study found IFN $\gamma$ mRNA and serum protein levels to be high in vitiligo patients [30]. Taken together these results suggest IFN $\gamma$ induced expression of MHC-I, MHC-II and TAP on melanocytes. Recently, it has been shown that IFN $\gamma$ induces senescence in melanocytes [164]. IFN $\gamma$ signaling impedes maturation of melanosomes by concerted downregulation of some pigmentation genes that leads to IFN $\gamma$-mediated hypo- pigmentation of melanocytes [165]. IFN $\gamma$ and TNFa induce the expression of ICAM1 on melanocytes [166]. We recently, reported increased levels of IFN $\gamma$, TNF $\alpha$ and TNF $\beta$ [29-31]. Levels of ICAM1 are found to be upregulated in melanocytes of peri-lesional of vitiligo patients [167]. Our recent study has also shown increased ICAM1 transcript levels in vitiligo patients [30]. T cell melanocyte binding is enhanced by increased expression of ICAM1 on melanocytes [167]. A melanocyte is in close association with $\sim 32$ keratinocytes in the epidermal melanin unit. Keratinocytes synthesize cytokines, such as TNFa, IL1 $\alpha$, IL6, and transforming growth factor $\beta$ (TGF $\beta$ ), which are paracrine inhibitors of melanocyte proliferation and melanogenesis. In numerous cell types, TNFa plays an important role in apoptosis through activation of the receptor-mediated apoptotic pathway [168]. Moreover, TNF $\alpha$ can also inhibit melanocyte stem cell differentiation [169]. NACHT leucine-rich repeat protein 1 (NLRP1), known to be involved in inflammation and apoptosis [170,171], modulates the response of cells towards proinflammatory cytokines such as IL1 $\beta$, IFN $\gamma$ and TNFa. Recently, we have found increased expression of NLRP1 in vitiligo patients [172]. Bassiouny et al. [173] have found increased level of IL17 and its positive correlation with disease pregression in both the lesional skin and sera of vitiligo patients. Zhao et al. [174] found decreased levels of anti-inflammatory cytokine IL10 in vitiligo patients. All the above studies indicate the significant role of immune mechanisms in the progression of vitiligo that finds support from the reported favourable response to immunosuppressive treatments [175].

\section{Cross Talk between Oxidative Stress, ER stress and Immune System in Vitiligo}

Vitiligo is believed to be a multifactorial, polygenic disorder and the exact underlying mechanisms and involvement of specific triggering factors are hitherto not well understood. Several hypotheses have been proposed for explaining the disappearance of melanocytes. We aim to link the plausible components identified in various hypotheses that may help detect the potential pathways participating in vitiligo pathogenesis and also understand the possible etiology of vitiligo. Numerous studies indicate possible cross talk between ER and oxidative stresses; however the mechanistic link is not fully understood [98]. Oxygen-utilizing metabolic processes such as oxidative phosphorylation in mitochondria generate ROS. ER provides a favorable oxidizing environment for protein folding and disulfide bond formation before transport to Golgi. Protein misfolding in the ER may lead to ROS generation through some possible mechanisms- (i) Binding of misfolded proteins to chaperones like BiP that consumes ATP can result in compensatory increase in oxidative phosphorylation in mitochondria and consequent generation of ROS and (ii) ROS may also be produced during disulfide bond formation and protein folding in the ER by way of transfer of electrons from thiol groups in folding substrates catalyzed by Protein Disulfide Isomerase (PDI) and ER Oxidoreductase 1 (ERO1) to molecular oxygen leading to the formation of $\mathrm{H}_{2} \mathrm{O}_{2}$ [176-178]. Protein misfolding in the ER lumen can cause escape of $\mathrm{Ca}^{2+}$ from the ER [179] that will be taken up by mitochondria wherein they can cause disruption in the electron transport chain. Oxidation of cysteine residues during disulfide bond formation in the ER may considerably contribute to oxidative stress [176,177]. Malhotra et al. [180] have shown that accumulation of unfolded proteins in the ER lumen is sufficient to produce ROS and that both ROS and unfolded proteins are required in concert to activate the UPR and apoptosis. These findings propose that unfolded proteins in the ER lumen signal ROS formation and they in turn can act as second messengers to activate UPR and induce apoptosis. Increasing evidence tends to suggest the expression of immunoglobulin heavychain binding protein (BiP)/ glucose-regulated protein 78 (GRP78), calnexin, calreticulin (CRT), GRP94 /gp96, oxygen regulated protein 150 (ORP150)/ GRP170, homocysteine-induced ER protein (Herp) and heat shock protein 47 (hsp47)/ SerpinH1 during ER stress, a few of which also present at the cell surface, can play pathophysiological roles as pro- or anti-inflammatory factors in autoimmune and inflammatory diseases [181,182]. GRP78 is a molecular chaperone, also known as BiP, initiates signaling cascades of UPR [183] (Figure 2). Various reports that show participation of GRP78 in antibody generation, $\mathrm{T}$ cell proliferation, and pro-inflammatory cytokine production can therefore serve as one of the potential factors in the precipitation of autoimmune diseases [184-186]. Xue et al. [187] have 
demonstrated TNFa induction of UPR, including PERK-mediated eIF2 $\alpha$ phosphorylation, and ATF6- and IRE1-mediated induction of sXBP1, by way of ROS-dependent pathways. Reported autoimmune mediated $\beta$-cell destruction in type 1 diabetes by ER stress [188,189] provides support to the above contention. Involvement of UPR in the pathogenesis of vitiligo is suggested by the presence of dilated ER in the peri-lesional skin of vitiligo patients [72]. It is well accepted that the presence of antimelanocyte antibodies can serve as a marker for the initiation and progression of autoimmunity in vitiligo [10,32,146]. Studies have shown IRE1 modulation of antibody producing B cell proliferation. Scarcity of IRE1is shown to hinder differentiation of pro-B cells into pre-B cells [190] while, XBP1 is essential for antibody production by mature B cells [191]. B-cell receptor (BCR) is reported to induce ubiquitin-mediated degradation of BCL-6, a repressor for $\mathrm{B}$ lymphocyte- induced maturation protein 1 (BLIMP1) [192]. BLIMP1 that downregulates the expression of B-cell lineage- specific activator protein (BSAP) [193] is suggested to function as a repressor for XBP1 [194]. Many studies have highlighted the importance of innate immunity in the pathogenesis of vitiligo $[40,131]$ while, components of the UPR pathway are known to regulate innate immune response [174]. Various models support the notion that an inadequate UPR and aberrant protein folding may contribute to autoimmunity through four possible mechanisms: (i) recognition of misfolded proteins by autoreactive immune cells; (ii) release of neo-auto antigens and UPR-related auto antigens by cells that are dying from unrecoverable levels of ER stress, with subsequent provocation of autoimmunity; (iii) indirect contributions to autoimmunity through impairment of immune-tolerance mechanisms in cells with an abnormal UPR and (iv) conferring resistance to UPR mediated apoptosis or a survival advantage to autoreactive cells by upregulating ERAD-associated proteins [46].

UPR is linked with inflammatory cytokines through various mechanisms including ROS, NF $\kappa$ B, and JNK. Excessive load of protein folding in ER may lead to oxidative stress [177]. The expression of ER stress-associated transcription factor, c-AMP responsive element binding protein $\mathrm{H}(\mathrm{CREBH})$,is stimulated by IL1 $\beta$ and IL6, which in turn govern the transcription of two critical factors implicated in innate immune response i.e., serum amyloid P-component and Creactive protein [190]. Furthermore, the differentiation of dendritic cells (DCs) is regulated by XBP1 [195]. Increased levels of XBP1 mRNA splicing are found in DCs and, XBP1 deficient mice showed altered development of both conventional and plasmacytoid DCs. XBP1 deficient DCs are at risk to ER stress-induced apoptosis [195]. Additionally, IL23 secretion from DCs is regulated by CHOP. CHOP directly binds to IL23 gene and regulate its transcription [196]. Vitiligo inducing phenols trigger UPR in melanocytes and upregulate the expression of IL6, and IL8. Co-treatment with XBP1 inhibitor reduces IL6 and IL8 production induced by phenols while, overexpression of XBP1 alone increases their expression [41]. Interestingly, increased expression of XBP1 has been observed in lesional skin of vitiligo [117], emphasizing its involvement in ER stress and autoimmune mediated melanocyte destruction. Apart from IRE1, the PERK pathway of UPR is also associated with innate immune response. PERK signaling is reported to activate antioxidant pathway by promoting ATF4 and nuclear factor-erythroid-derived 2-related factor 2 (NRF2) [176,197] whereas, loss of PERK enhances ROS accumulation induced by toxic chemicals $[176,198]$. The IRE1 pathway can recruit $\mathrm{I} \kappa \mathrm{B}$ kinase (IKK), leading to the activation of $\mathrm{NF} \kappa \mathrm{B}$, an important regulator of inflammation [199].

As a result, $\mathrm{NF} \kappa \mathrm{B}$ activation and $\mathrm{TNF} \alpha$ production are reduced in cells lacking IRE1 [199]. Our previous study has shown increased TNFa levels in vitiligo patients [29] and TNFa has shown to induce UPR in an ROS-dependent manner [187]. In contrast to TNFa, oxidative stresses by $\mathrm{H}_{2} \mathrm{O}_{2}$ or arsenite only induces eIF $2 \alpha$ phosphorylation, but not activation of PERK- or IRE1-dependent pathways, indicating the specificity of downstream signaling induced by various oxidative stressors. Furthermore, the IRE1 pathway activates JNK, inducing the expression of inflammatory genes by activating activator protein 1 (AP1) [200]. ATF6 can also activate $\mathrm{NF} \kappa \mathrm{B}$ pathway [201].

Cytokines have been evidenced to activate the expression of inducible nitric oxide synthase (iNOS), leading to excessive Nitric Oxide (NO) production. Interestingly, cytokines are reported to induce ER stress via iNOS and JNK pathways. NO has also been suggested to be an important mediator of cell death. Inflammatory cytokines including IL1 $\beta$, IFN $\gamma$ and TNF $\alpha$ can induce iNOS expression which then produces copious amount of NO [202]. JNK pathway is activated by IL1 $\beta$ [203]. Activation of ER stress pathway is stimulated by IL1 $\beta$ and IFN $\gamma$ leading to apoptosis via NO synthesis [204]. Our previous studies have shown increased expression levels of TNFA [29], IFNG [30] and IL1B [205] in patients with vitiligo. Increased level of NO induces DNA damage and results in apoptosis via p53 pathway or necrosis via poly (ADP-ribose) polymerase (PARP) pathway [206] In addition, $\mathrm{NO}$ depletes $\mathrm{ER} \mathrm{Ca}^{2+}$ storage by means of activating $\mathrm{Ca}^{2+}$ channels or inhibiting $\mathrm{Ca}^{2+}$ pumps [207,208]. Depleted ER Ca ${ }^{2+}$ levels leads to ER stress and apoptosis through induction of CHOP signaling [209]. Imbalance of various pro-inflammatory and anti-inflammatory cytokines has been reported in the microenvironment of vitiliginious skin. IL17 works to activate the production of other cytokines, including IL1 and IL6, and can potentiate other local inflammatory mediators like TNFa $[173,210]$. Keratinocyte dysfunction along with increased TNFa and IL6 production has been reported in vitiligo patients [211]. $\mathrm{H}_{2} \mathrm{O}_{2}$ is known to induce NFkB in nuclear extracts and increase phosphorylated p38 MAPK levels in cells. NFkB is present in the cytoplasm as an inactive $\mathrm{NFkB}$ complex. In response to various stimuli, the latent cytoplasmic $\mathrm{NFkB} / \mathrm{IkBa}$ complex dissociates and activated NFkB translocates to the nucleus and induces the expression of relevant genes, including various cytokines genes [212]. The build-up of ROS causes protein misfolding in the ER which, may result in possible immune system defects precipitating inappropriate autoimmune response against melanocytes (Figure 3). Calreticulin (CRT) is a ubiquitous protein localized predominantly in the ER and plays a major role in intracellular $\mathrm{Ca}^{2+}$ homeostasis [213-216]. Cell surface localization of CRT has been reported on T cells, neutrophils, monocytes, macrophages and dendritic cells [217-220]. Localization of cell surface CRT reportedly affects antigen presentation, complement activation [221-223] and clearance of apoptotic cells [218]. Recently, Zhang et al. [224] have reported increased CRT expression in response to $\mathrm{H}_{2} \mathrm{O}_{2}$ in human melanocytes leading to apoptosis. In addition, CRTtreated peripheral blood mononuclear cells or stressed melanocytes show higher IL6 and TNFa levels. Higher CRT expression in vitiligo patients is positively correlated with lesion area and duration of disease. The exposure of CRT on the plasma membrane can precede anthracycline-induced apoptosis and is required for cell death to be perceived as immunogenic [225]. Several studies have found translocation of intracellular CRT to the cell surface in response to anthracycline and high doses of irradiation in a variety of human and rodent cancer cells, including melanoma [226-228]. Surface CRT then initiates an apoptotic signal [229] which is critical for the recognition and engulfment by DCs. In contrast, apoptotic cells have been suggested to be phagocytized because of their lack of CD47 expression and the coordinated upregulation of cell surface CRT in fibroblasts, neutrophils, and Jurkat T cells [218]. Interestingly, Zhang et al. [224] 


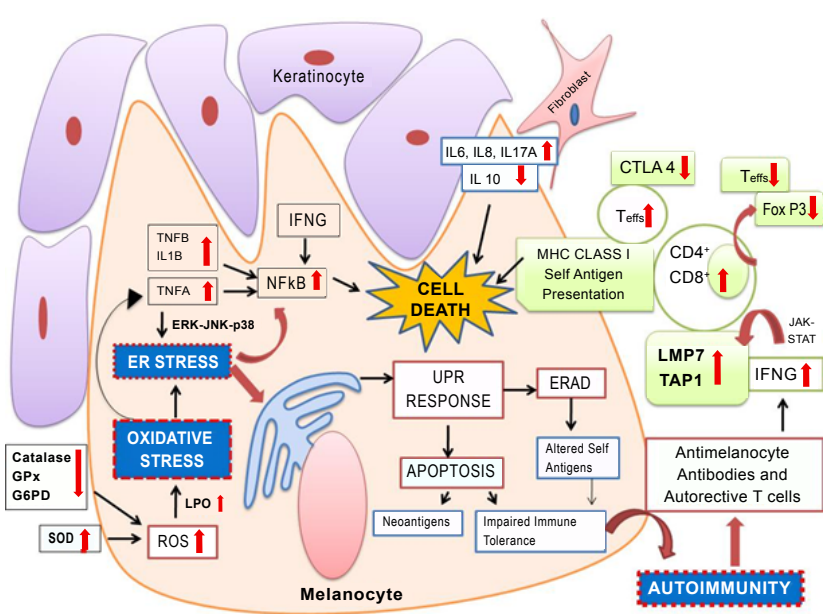

Figure 3: Cross talk between oxidative stress, ER stress and immune System in melanocyte death: Decrease in antioxidant enzymes leads to ROS formation, ultimately leading to oxidative stress. Oxidative stress induces ER stress leading to activation of Unfolded Protein Response (UPR) which in turn activates autoimmune response. [Abbreviations: GPx (Glutathione Peroxidase), G6PD (Glucose 6 Phosphate Dehydrogenase), SOD (Superoxide Dismutase), LPO (Lipid Peroxidation), ROS (Reactive Oxygen Species), TNFA (Tumor Necrosis Factor- alpha), TNFB (Tumor Necrosis Factor - beta), IL1B (Interleukin 1-beta), NFkB (Nuclear Factor kappa - beta), IFNG (Interferon -gamma), UPR (Unfolded Protein Response), ERAD (Endoplasmic Reticulum Associated Degradation), LMP7 (Low Molecular Weight Polypeptide 7), TAP1 (Transporter Associated With Antigen Processing 1), Treg (T regulatory Cells), Teff (T effector cells), (Interleukins - IL6, IL8, IL10, IL17A), CTLA4 (Cytotoxic T Lymphocyte Antigen 4)]

have shown increased surface levels of CRT in response to $\mathrm{H}_{2} \mathrm{O}_{2}$ and this correlates with decreased CD47 levels, suggesting increased susceptibility to $\mathrm{H}_{2} \mathrm{O}_{2}$ mediated oxidative stress induced apoptosis [230]. These findings demonstrate translocation of CRT to the cell surface, via $\mathrm{H}_{2} \mathrm{O}_{2}$ induced oxidative stress to play an essential role in melanocyte apoptosis suggesting a relationship between apoptosis and immune responses during melanocyte destruction. Nevertheless, the relationship between CRT and ROS-induced apoptosis in melanocytes is still not fully explored. However, the defective $\mathrm{Ca}^{2+}$ homeostasis in vitiligo patients $[90,91]$ certainly proposes a crucial role of CRT and thus the ER stress in vitiligo pathogenesis.

Cells under stress halt typical protein synthesis in favor of heatshock protein (HSP) and/ GRP synthesis [231,232]. In the ER, this can induce the UPR which upregulates HSPs [233]. Among larger HSPs, inducible HSP70 (HSP70i) is unique for its secretion from cells as a chaperokine [234]. The unique secretory property of HSP70i may be attributed at least in part to its cellular location, associated with melanosomes [235]. HSP70i is exported by cells through the endolysosomal pathway [236]. A rise in intracellular $\mathrm{Ca}^{2+}$ serves as a signal for exocytosis [237].

HSP70i can stimulate proliferation and cytotoxicity of NK cells [238], and enhances leukotriene secretion by mast cells [239]. Moreover, HSP70i has shown to induce maturation and type1 polarizing cytokine production by DCs and stimulate crosspriming of $\mathrm{T}$ cells [241], breaking the tolerance and inducing autoimmune mediated tissue destruction in mice [241]. Mosenson et al. [242] reported that modified HSP70i prevents T cell-mediated depigmentation. In addition, they have also shown HSP70i induces an inflammatory DC phenotype in both vitiligo mouse models as well as in vitiligo patients, which is necessary for depigmentation [242,243]. Interestingly, mutant HSP70iQ435A has been shown to prevent and reverse the depigmentation in different mouse models prone to vitiligo. These findings indicate a vital role of HSP70 in precipitation of vitiligo and targeting HSP70i might be a promising approach towards the treatment of vitiligo [242-244].

Genetic and pathophysiological studies provide strong evidence for vitiligo to be a polygenic, multifactorial disorder. The genome-wide association studies provide a partial explaination for the heritability of vitiligo but polymorphism in various candidate genes may play a crucial role in the disease phenotype, such as progression or age of onset [245]. Most vitiligo susceptibility loci encode melanocyte components, and antioxidant and immune-regulatory proteins $[40,246]$. For example, associations have been established between vitiligo pathogenesis and polymorphisms in tyrosinase (TYR) [247], catalase (CAT) [65], glutathione peroxidase $(G P X)[65]$, melanocortin 1 receptor $(M C 1 R)$ [248], major histocompatibility complex (MHC) [249], NACHT leucine-rich repeat protein 1 (NLRP1) [172], tumor necrosis factor A (TNFA) [29], interferon- $\gamma$ (IFNG) [30], intercellular adhesion molecule-1 (ICAM1) [30], tumor necrosis factor B (TNFB) [31], superoxide dismutase $(S O D)$ [58], cytotoxic T lymphocyte associated antigen 4 (CTLA4) [250], interleukin 4 (IL4) [28], melanocyte proliferating gene (MYG1) [251], X-box binding protein 1 (XBP1) [117], and methylenetetrahydrofolate reductase (MTHFR) [252]. Both protective and susceptibility-increasing effects have been found in the case of different polymorphisms in these genes [253,254]. Interestingly, our recent study on skin miRNA profiling from non-segmental vitiligo have shown 38 differentially expressed miRNA signatures in patients [255]. In the light of the above studies, it can be proposed that ER stress could also result due to variations at genetic levels involving the genes participating in the specific pathways contributing to ER function in these patients.

\section{Conclusions}

The cross talk between oxidative stress, ER stress and autoimmunity appears crucial and may emerge as a critical aspect of vitiligo pathogenesis. The present article suggests that oxidative stress may be the initial triggering event to precipitate vitiligo, which is then exacerbated by contribution of ER and autoimmune factors together with oxidative stress. However, more detailed studies focusing on ER stress are required for underlying the major role of ER stress in oxidative stress and autoimmunity mediated pathogenesis of vitiligo. Further, delineation of the melanocyte-specific UPR would be of significance in developing and evaluating the efficacy of response modifying compounds that can be used to prevent melanocyte death in vitiligo.

\section{References}

1. Taieb A, Picardo M (2007) The definition and assessment of vitiligo: consensus report of the Vitiligo European Task Force. Pigment Cell Res 20: 27-35.

2. Agrawal D, Sahani MH, Gupta S, Begum R (2001) Vitiligo -etiopathogenesis and therapy. J MS University of Baroda (Sci., Tech. And Med) 48: 97-106.

3. Huggins RH, Schwartz RA, Janniger CK (2005) Vitiligo. Acta Dermatovenerol Alp Panonica Adriat 14: 137-142, 144-145.

4. Taieb A, Picardo M (2009) Clinical practice. Vitiligo. N Engl J Med 360: 160169.

5. Mehta NR, Shah KC, Theodore C, Vyas VP, Patel AB (1973) Epidemiological study of vitiligo in Surat area, South Gujarat. Indian J Med Res 61: 145-54.

6. Parsad D, Pandhi R, Dogra S, Kanwar AJ, Kumar B (2003) Dermatology life quality index score in vitiligo and its impact on the treatment outcome. $\mathrm{Br} \mathrm{J}$ Dermatol 148: 373-374.

7. Noh S, Kim M, Park CO, Hann SK, Oh SH (2013) Comparison of the 
psychological impacts of asymptomatic and symptomatic cutaneous diseases: vitiligo and atopic dermatitis. Ann Dermatol 25: 454-461.

8. Silverberg JI, Silverberg NB (2014) Quality of life impairment in children and adolescents with vitiligo. Pediatr Dermatol 31: 309-318.

9. Al-Shobaili HA (2014) Correlation of clinical efficacy and psychosocial impact on vitiligo patients by excimer laser treatment. Ann Saudi Med 34: 115-121.

10. Alkhateeb A, Fain PR, Thody T, Bennett DC, Spritz RA (2003) Vitiligo and associated autoimmune diseases in Caucasian probands and their families. Pigment Cell Res 16: 208-214.

11. Boelaert K, Newby PR, Simmonds MJ, Holder RL, Carr-Smith JD, et al. (2010) Prevalence and relative risk of other autoimmune diseases in subjects with autoimmune thyroid disease. Am J Med 123: 183.

12. Shajil EM, Rasheedunnisa B (2006) Antioxidant status of segmental and nonsegmental vitiligo. Pig Cell Res 19: 179-180.

13. Kostopoulou P, Jouary T, Quintard B, Ezzedine K, Marques S, et al. (2009) Objective versus subjective factors in the psychological impact of vitiligo: the experience from a French referral centre. $\mathrm{Br} \mathrm{J}$ Dermatol 161: 128-133.

14. Mashayekhi V, Javidi Z, Kiafar B, Manteghi AA, Saadatian V, et al. (2010) Quality of life in patients with vitiligo: a descriptive study on 83 patients attending a PUVA therapy unit in Imam Reza Hospital, Mashad. Indian J Dermatol Venereol Leprol 76: 592.

15. Wang KY, Wang KH, Zhang ZP (2011) Health-related quality of life and marita quality of vitiligo patients in China. J Eur Acad Dermatol Venereol 25: 429-435.

16. Kemp EH, Waterman EA, Weetman AP (2001) Autoimmune aspects of vitiligo. Autoimmunity $34: 65-77$.

17. Ongenae K, Van Geel N, Naeyaert JM (2003) Evidence for an autoimmune pathogenesis of vitiligo. Pigment Cell Res 16: 90-100.

18. Picardo M, Taieb A (2010) Vitiligo. (1stedn), Springer, Heidelberg

19. Kroll TM, Bommiasamy H, Boissy RE, Hernandez C, Nickoloff BJ, et al. (2005) 4-Tertiary butyl phenol exposure sensitizes human melanocytes to dendritic cell-mediated killing: relevance to vitiligo. J Invest Dermatol 124: 798-806.

20. van den Boorn JG, Picavet DI, van Swieten PF, van Veen HA, Konijnenberg $D$, et al. (2011) Skin-depigmenting agent monobenzone induces poten T-cell autoimmunity toward pigmented cells by tyrosinase haptenation and melanosome autophagy. J Invest Dermatol 131: 1240-1251.

21. Castanet J, Ortonne JP (1997) Pathophysiology of vitiligo. Clin Dermatol 15 845-851.

22. Honda Y, Okubo Y, Koga M (1997) Relationship between levels of soluble interleukin-2 receptors and the types and activity of vitiligo. J Dermatol 24: 561563

23. Yu HS, Chang KL, Yu CL, Li HF, Wu MT, et al. (1997) Alterations in IL-6, IL-8, GM-CSF, TNF-alpha, and IFN-gamma release by peripheral mononuclear cells in patients with active vitiligo. J Invest Dermatol 108: 527-529.

24. Caixia T, Hongwen F, Xiran L (1999) Levels of soluble interleukin-2 receptor in the sera and skin tissue fluids of patients with vitiligo. J Dermatol Sci 21: 59-62.

25. Moretti S, Spallanzani A, Amato L, Hautmann G, Gallerani I, et al. (2002) New insights into the pathogenesis of vitiligo: imbalance of epidermal cytokines at sites of lesions. Pigment Cell Res 15: 87-92

26. Zailaie MZ (2005) Decreased proinflammatory cytokine production by periphera blood mononuclear cells from vitiligo patients following aspirin treatment. Saudi Med J 26: 799-805.

27. Grimes PE (2004) White patches and bruised souls: advances in the pathogenesis and treatment of vitiligo. J Am Acad Dermatol 51: S5-7.

28. Imran M, Laddha NC, Dwivedi M, Mansuri MS, Singh J, et al. (2012) Interleukin-4 genetic variants correlate with its transcript and protein levels in patients with vitiligo. Br J Dermatol 167: 314-323.

29. Laddha NC, Dwivedi M, Begum R (2012) Increased Tumor Necrosis Factor (TNF)-Ît and its promoter polymorphisms correlate with disease progression and higher susceptibility towards vitiligo. PLoS One 7: e52298.

30. Dwivedi M, Laddha NC, Shah K, Shah BJ, Begum R (2013) Involvement of interferon-gamma genetic variants and intercellular adhesion molecule-1 in onset and progression of generalized vitiligo. J Interferon Cytokine Res 33 646-659.
31. Laddha NC, Dwivedi M, Gani AR, Mansuri MS, Begum R (2013) Tumor necrosis factor $B$ (TNFB) genetic variants and its increased expression are associated with vitiligo susceptibility. PLoS One 8: e81736.

32. Laddha NC, Dwivedi M, Mansuri MS, Singh M, Gani AR, et al. (2014) Role of oxidative stress and autoimmunity in onset and progression of vitiligo. Exp Dermatol 23: 352-353.

33. Maresca V, Roccella M, Roccella F, Camera E, Del Porto G, et al. (1997) Increased sensitivity to peroxidative agents as a possible pathogenic factor of melanocyte damage in vitiligo. J Invest Dermatol 109: 310-313.

34. Hensley K, Robinson KA, Gabbita SP, Salsman S, Floyd RA (2000) Reactive oxygen species, cell signaling, and cell injury. Free Radic Biol Med 28: 14561462.

35. Nordberg J, Arnér ES (2001) Reactive oxygen species, antioxidants, and the mammalian thioredoxin system. Free Radic Biol Med 31: 1287-1312.

36. Schallreuter KU (1999) Successful treatment of oxidative stress in vitiligo. Skin Pharmacol Appl Skin Physiol 12: 132-138

37. Bowers RR, Lujan J, Biboso A, Kridel S, Varkey C (1994) Premature avian melanocyte death due to low antioxidant levels of protection: fowl model fo vitiligo. Pigment Cell Res 7: 409-418.

38. Knight JA (1995) Diseases related to oxygen-derived free radicals. Ann Clin Lab Sci 25: 111-121

39. Yildirim M, Baysal V, Inaloz HS, Can M (2004) The role of oxidants and antioxidants in generalized vitiligo at tissue level. J Eur Acad Dermatol Venereol 18: $683-686$.

40. Laddha NC, Dwivedi M, Mansuri MS, Gani AR, Ansarullah M, et al. (2013) Vitiligo: interplay between oxidative stress and immune system. Exp Dermato 22: $245-250$

41. Toosi S, Orlow SJ, Manga P (2012) Vitiligo-inducing phenols activate the unfolded protein response in melanocytes resulting in upregulation of IL6 and IL8. J Invest Dermatol 132: 2601-2609.

42. Lipson KL, Fonseca SG, Urano F (2006) Endoplasmic reticulum stress-induced apoptosis and auto-immunity in diabetes. Curr Mol Med 6: 71-77.

43. Ron D, Walter $P$ (2007) Signal integration in the endoplasmic reticulum unfolded protein response. Nat Rev Mol Cell Biol 8: 519-529.

44. Fonseca SG, Burcin M, Gromada J, Urano F (2009) Endoplasmic reticulum stress in beta-cells and development of diabetes. Curr Opin Pharmacol 9: 763 770

45. Chen Y, Brandizzi F (2013) IRE1: ER stress sensor and cell fate executor Trends Cell Biol 23: 547-555

46. Todd DJ, Lee AH, Glimcher LH (2008) The endoplasmic reticulum stress response in immunity and autoimmunity. Nat Rev Immunol 8: 663-674.

47. Rokos H, Beazley WD, Schallreuter KU (2002) Oxidative stress in vitiligo: photo-oxidation of pterins produces $\mathrm{H}(2) \mathrm{O}(2)$ and pterin-6-carboxylic acid Biochem Biophys Res Commun 292: 805-811.

48. Schallreuter KU, Moore J, Wood JM, Beazley WD, Peters EM, et al. (2001) Epidermal $\mathrm{H}(2) \mathrm{O}(2)$ accumulation alters tetrahydrobiopterin $(6 \mathrm{BH} 4)$ recycling in vitiligo: identification of a general mechanism in regulation of all $6 \mathrm{BH} 4$ dependent processes? J Invest Dermatol 116: 167-174.

49. Shaker OG, El-Tahlawi SM (2008) Is there a relationship between homocysteine and vitiligo? A pilot study. Br J Dermatol 159: 720-724

50. Salem MM, Shalbaf M, Gibbons NC, Chavan B, Thornton JM, et al. (2009) Enhanced DNA binding capacity on up-regulated epidermal wild-type p53 in vitiligo by $\mathrm{H} 2 \mathrm{O} 2-$ mediated oxidation: a possible repair mechanism for DNA damage. FASEB J 23: 3790-3807.

51. Beazley WD, Gaze D, Panske A, Panzig E, Schallreuter KU (1999) Serum selenium levels and blood glutathione peroxidase activities in vitiligo. $\mathrm{Br} \mathrm{J}$ Dermatol 141: 301-303.

52. Weiss N, Zhang YY, Heydrick S, Bierl C, Loscalzo J (2001) Overexpression of cellular glutathione peroxidase rescues homocyst(e)ine-induced endothelial dysfunction. Proc Natl Acad Sci U S A 98: 12503-12508.

53. Wang XW, Luo YL, Wang W, Zhang Y, Chen Q, et al. (2012) Association between MTHFR A1298C polymorphism and neural tube defect susceptibility: a metaanalysis. Am J Obstet Gynecol 206: 251.

54. Chen JX, Shi Q, Wang XW, Guo S, Dai W, et al. (2014) Genetic polymorphisms 
in the methylenetetrahydrofolate reductase gene (MTHFR) and risk of vitiligo in Han Chinese populations: a genotype-phenotype correlation study. $\mathrm{Br} \mathrm{J}$ Dermatol 170: 1092-1099.

55. Begum R (2014) Methylenetetrahydrofolate reductase (MTHFR): could it be a small piece in vitiligo jigsaw puzzle? Br J Dermatol 170: 1009-1010.

56. Koca R, Armutcu F, Altinyazar HC, Gürel A (2004) Oxidant-antioxidant enzymes and lipid peroxidation in generalized vitiligo. Clin Exp Dermatol 29: 406-409.

57. Sravani PV, Babu NK, Gopal KV, Rao GR, Rao AR, et al. (2009) Determination of oxidative stress in vitiligo by measuring superoxide dismutase and catalase levels in vitiliginous and non-vitiliginous skin. Indian J Dermatol Venereol Leprol 75: 268-271

58. Laddha NC, Dwivedi M, Gani AR, Shajil EM, Begum R (2013) Involvement of superoxide dismutase isoenzymes and their genetic variants in progression of and higher susceptibility to vitiligo. Free Radic Biol Med 65: 1110-1125.

59. Picardo M, Passi S, Morrone A, Grandinetti M, Di Carlo A, et al. (1994) Antioxidant status in the blood of patients with active vitiligo. Pigment Cell Res 7: 110-115.

60. Agrawal D, Shajil EM, Marfatia YS, Begum R (2004) Study on the antioxidant status of vitiligo patients of different age groups in Baroda. Pigment Cell Res 17: $289-294$

61. Dell'Anna ML, Urbanelli S, Mastrofrancesco A, Camera $E$, lacovelli $P$, et al. (2003) Alterations of mitochondria in peripheral blood mononuclear cells of vitiligo patients. Pigment Cell Res 16: 553-559.

62. Halliwell B, Gutteridge JM, Cross CE (1992) Free radicals, antioxidants, and human disease: where are we now? J Lab Clin Med 119: 598-620.

63. Dammak I, Boudaya S, Ben Abdallah F, Turki H, Attia H, et al. (2009) Antioxidant enzymes and lipid peroxidation at the tissue level in patients with stable and active vitiligo. Int J Dermatol 48: 476-480.

64. Hazneci E, Karabulut AB, OztÃ¹/4rk C, BatÃß̧ioÄŸlu K, DoÄŸan G, et al. (2005) A comparative study of superoxide dismutase, catalase, and glutathione peroxidase activities and nitrate levels in vitiligo patients. Int J Dermatol 44 $636-640$

65. Em S, Laddha NC, Chatterjee S, Gani AR, Malek RA, et al. (2007) Association of catalase T/C exon 9 and glutathione peroxidase codon 200 polymorphisms in relation to their activities and oxidative stress with vitiligo susceptibility in Gujarat population. Pigment Cell Res 20: 405-407.

66. Hasse S, Gibbons NC, Rokos H, Marles LK, Schallreuter KU (2004) Perturbed 6 -tetrahydrobiopterin recycling via decreased dihydropteridine reductase in vitiligo: more evidence for H2O2 stress. J Invest Dermatol 122: 307-313.

67. Schallreuter KU, Moore J, Wood JM, Beazley WD, Gaze DC, et al. (1999) In vivo and in vitro evidence for hydrogen peroxide ( $\mathrm{H} 2 \mathrm{O} 2)$ accumulation in the epidermis of patients with vitiligo and its successful removal by a UVB-activated pseudocatalase. J Investig Dermatol Symp Proc 4: 91-96.

68. Schallreuter KU, Bahadoran P Picardo M, Slominski A, Elassiuty YE, et al. (2008) Vitiligo pathogenesis: autoimmune disease, genetic defect, excessive reactive oxygen species, calcium imbalance, or what else? Exp Dermatol 17 $139-140$

69. Jain D, Misra R, Kumar A, Jaiswal G (2008) Levels of malondialdehyde and antioxidants in the blood of patients with vitiligo of age group 11-20 years. Indian J Physiol Pharmacol 52: 297-301.

70. Khan R, Satyam A, Gupta S, Sharma VK, Sharma A (2009) Circulatory levels of antioxidants and lipid peroxidation in Indian patients with generalized and localized vitiligo. Arch Dermatol Res 301: 731-737.

71. Bhawan J, Bhutani LK (1983) Keratinocyte damage in vitiligo. J Cutan Pathol 10: $207-212$.

72. Boissy RE, Liu YY, Medrano EE, Nordlund JJ (1991) Structural aberration of the rough endoplasmic reticulum and melanosome compartmentalization in long-term cultures of melanocytes from vitiligo patients. J Invest Dermatol 97 395-404.

73. Moellmann G (1992) Keratinocytes in vitiligo. J Invest Dermatol 99: 665

74. Tobin DJ, Swanson NN, Pittelkow MR, Peters EM, Schallreuter KU (2000) Melanocytes are not absent in lesional skin of long duration vitiligo. J Patho 191: 407-416.

75. Kops GJ, Dansen TB, Polderman PE, Saarloos I, Wirtz KW, et al. (2002)
Forkhead transcription factor FOXO3a protects quiescent cells from oxidative stress. Nature 419: 316-321.

76. Nemoto S, Finkel T (2002) Redox regulation of forkhead proteins through a p66shc-dependent signaling pathway. Science 295: 2450-2452.

77. Chiribau CB, Cheng L, Cucoranu IC, Yu YS, Clempus RE, et al. (2008) FOXO3A regulates peroxiredoxin III expression in human cardiac fibroblasts. J Biol Chem 283: 8211-8217

78. Brunet A, Bonni A, Zigmond MJ, Lin MZ, Juo P, et al. (1999) Akt promotes cell survival by phosphorylating and inhibiting a Forkhead transcription factor. Cell 96: 857-868.

79. Furukawa-Hibi Y1, Kobayashi Y, Chen C, Motoyama N (2005) FOXO transcription factors in cell-cycle regulation and the response to oxidative stress. Antioxid Redox Signal 7: 752-760.

80. Olmos Y, Valle I, Borniquel S, Tierrez A, Soria E, et al. (2009) Mutual dependence of Foxo3a and PGC-1alpha in the induction of oxidative stress genes. J Biol Chem 284: 14476-14484.

81. Yalcin S, Zhang X, Luciano JP, Mungamuri SK, Marinkovic D, et al. (2008) Foxo3 is essential for the regulation of ataxia telangiectasia mutated and oxidative stress-mediated homeostasis of hematopoietic stem cells. J Biol Chem 283: 25692-25705

82. Ozel Turkcu U, Tekin NS2, Edgunlu TG3, Karakas SC4, Oner S5 (2013) The association of Foxo3a gene polymorphisms with serum Foxo3a levels and oxidative stress markers in vitiligo patients. Gene.

83. Reedy MV, Parichy DM, Erickson CA, Mason KA, Frost- Mason SK (1998) Regulation of melanoblasts migration and differentiation. In: Nordlund $\mathrm{JJ}$ Boissey RE, Hearing VJ, King RA, Ortonne JP, editors. The Pigmentary system. Physiology and pathophysiology. Oxford University Press: New York.

84. lyengar B (1989) Modulation of melanocytic activity by acetylcholine. Acta Anat (Basel) 136: 139-141.

85. Elwary SM1, Headley K, Schallreuter KU (1997) Calcium homeostasis influences epidermal sweating in patients with vitiligo. $\mathrm{Br} \mathrm{J}$ Dermatol 137: 8185.

86. Schallreuter KU, Elwary SM, Gibbons NC, Rokos H, Wood JM (2004) Activation/deactivation of acetylcholinesterase by $\mathrm{H} 2 \mathrm{O} 2$ : more evidence for oxidative stress in vitiligo. Biochem Biophys Res Commun 315: 502-508.

87. Shajil EM, Marfatia YS, Begum R (2006) Acetylcholine esterase levels in different clinical types of vitiligo in Baroda, Gujarat. Ind J of Dermatol 51: 289291.

88. Circu ML, Aw TY (2010) Reactive oxygen species, cellular redox systems, and apoptosis. Free Radic Biol Med 48: 749-762.

89. Fulda S, Gorman AM, Hori O, Samali A (2010) Cellular stress responses: cell survival and cell death. Int J Cell Biol 2010: 214074.

90. Schallreuter KU, Pittelkow MP (1988) Defective calcium uptake in keratinocyte cell cultures from vitiliginous skin. Arch Dermatol Res 280: 137-139.

91. Schallreuter KU, Wood JM, Pittelkow MR, Buttner G, Swanson N, et al. (1996) Increased monoamine oxidase A activity in the epidermis of patients with vitiligo. Arch Dermatol Res 288: 14-18.

92. Tabas I, Ron D (2011) Integrating the mechanisms of apoptosis induced by endoplasmic reticulum stress. Nat Cell Biol 13: 184-190.

93. Hetz C (2012) The unfolded protein response: controlling cell fate decisions under ER stress and beyond. Nat Rev Mol Cell Biol 13: 89-102.

94. Cao SS, Kaufman RJ (2012) Unfolded protein response. Curr Biol 22: R622 626.

95. Schroder M, Kaufman RJ (2005) ER stress and the unfolded protein response. Mutat Res 569: 29-63.

96. Nakagawa T, Zhu H, Morishima N, Li E, Xu J, et al. (2000) Caspase-12 mediates endoplasmic-reticulum-specific apoptosis and cytotoxicity by amyloid-beta. Nature 403: 98-103.

97. Tan Y, Dourdin N, Wu C, De Veyra T, Elce JS, et al. (2006) Ubiquitous calpains promote caspase-12 and JNK activation during endoplasmic reticulum stress induced apoptosis. J Biol Chem 281: 16016-16024.

98. Malhotra JD, Kaufman RJ (2007) The endoplasmic reticulum and the unfolded protein response. Semin Cell Dev Biol 18: 716-731. 
99. Min SK, Lee SK, Park JS, Lee J, Paeng JY, et al. (2008) Endoplasmic reticulum stress is involved in hydrogen peroxide induced apoptosis in immortalized and malignant human oral keratinocytes. J Oral Pathol Med 37: 490-498.

100. Pallepati P, Averill-Bates DA (2011) Activation of ER stress and apoptosis by hydrogen peroxide in HeLa cells: protective role of mild heat preconditioning at $40^{\circ} \mathrm{C}$. Biochim Biophys Acta 1813: 1987-1999.

101. Fischer H, Koenig U, Eckhart L, Tschachler E (2002) Human caspase 12 has acquired deleterious mutations. Biochem Biophys Res Commun 293: 722 726.

102.Won SJ, Ki YS, Chung KS, Choi JH, Bae KH, et al. (2010) 3ît,23isopropylidenedioxyolean-12-en-27-oic acid, a triterpene isolated from Aceriphyllum rossii, induces apoptosis in human cervical cancer HeLa cells through mitochondrial dysfunction and endoplasmic reticulum stress. Bio Pharm Bull 33: 1620-1626.

103. Hu Q, Chang J, Tao L, Yan G, Xie M, et al. (2005) Endoplasmic reticulum mediated necrosis-like apoptosis of HeLa cells induced by $\mathrm{Ca} 2+$ oscillation. $J$ Biochem Mol Biol 38: 709-716.

104. Le Poole C, Boissy RE (1997) Vitiligo. Semin Cutan Med Surg 16: 3-14.

105. Le Poole IC, Boissy RE, Sarangarajan R, Chen J, Forristal JJ, et al. (2000) PIG3V, an immortalized human vitiligo melanocyte cell line, expresses dilated endoplasmic reticulum. In Vitro Cell Dev Biol Anim 36: 309-319.

106. Moellmann G, Klein-Angerer S, Scollay DA, Nordlund JJ, Lerner AB (1982) Extracellular granular material and degeneration of keratinocytes in the normally pigmented epidermis of patients with vitiligo. J Invest Dermatol 79: 321-330.

107. Galardi E, Mehregan AH, Hashimooto K (1993) Ultrastructural study of vitiligo. Int J Dermatol 32: 269-271.

108. Manga P, Bis S, Knoll K, Perez B, Orlow SJ (2010) The unfolded protein response in melanocytes: activation in response to chemical stressors of the endoplasmic reticulum and tyrosinase misfolding. Pigment Cell Melanoma Res 23: 627-634.

109. Gupta G, Sinha S, Mitra N, Surolia A (2009) Probing into the role of conserved $\mathrm{N}$-glycosylation sites in the Tyrosinase glycoprotein family. Glycoconj $\mathrm{J} 26$ : 691-695.

110. Wang N, Daniels R, Hebert DN (2005) The cotranslational maturation of the type I membrane glycoprotein tyrosinase: the heat shock protein 70 system hands off to the lectin-based chaperone system. Mol Biol Cell 16: 3740-3752.

111. Ujvari A, Aron R, Eisenhaure T, Cheng E, Parag HA, et al. (2001) Translation rate of human tyrosinase determines its $\mathrm{N}$-linked glycosylation level. $\mathrm{J}$ Bio Chem 276: 5924-5931.

112. Francis E, Wang N, Parag H, Halaban R, Hebert DN (2003) Tyrosinase maturation and oligomerization in the endoplasmic reticulum require melanocyte-specific factor. J Biol Chem 278: 25607-25617.

113. Toyofuku K, Wada I, Valencia JC, Kushimoto T, Ferrans VJ, et al. (2001) Oculocutaneous albinism types 1 and 3 are ER retention diseases: mutation of tyrosinase or Tyrp1 can affect the processing of both mutant and wild-type proteins. FASEB J 15: 2149-2161.

114. Chen K, Manga P, Orlow SJ (2002) Pink-eyed dilution protein controls the processing of tyrosinase. Mol Biol Cell 13: 1953-1964.

115. Costin GE, Valencia JC, Vieira WD, Lamoreux ML, Hearing VJ (2003) Tyrosinase processing and intracellular trafficking is disrupted in mouse primary melanocytes carrying the underwhite (uw) mutation. A model for oculocutaneous albinism (OCA) type 4. J Cell Sci 116: 3203-3212.

116. Halaban R, Svedine S, Cheng E, Smicun Y, Aron R, et al. (2000) Endoplasmic reticulum retention is a common defect associated with tyrosinase-negative albinism. Proc Natl Acad Sci U S A 97: 5889-5894.

117. Ren Y, Yang S, Xu S, Gao M, Huang W, et al. (2009) Genetic variation of promoter sequence modulates XBP1 expression and genetic risk for vitiligo. PLoS Genet 5: e1000523.

118. Jeong KH, Shin MK, Uhm YK, Kim HJ, Chung JH, et al. (2010) Association of TXNDC5 gene polymorphisms and susceptibility to nonsegmental vitiligo in the Korean population. Br J Dermatol 162: 759-764.

119. Oakes SA, Lin SS, Bassik MC (2006) The control of endoplasmic reticuluminitiated apoptosis by the BCL-2 family of proteins. Curr Mol Med 6: 99-109.

120. Abdel-Aal AM, Kasem MA, Abdel-Rahman AH (2002) Evaluation of the Role of Apoptosis in Vitiligo: Immunohistochemical Expression of P53, Bcl-2 and MART-1.

121. GARB J, WISE F (1948) Vitiligo with raised borders. Arch Derm Syphilol 58 149-153.

122. BUCKLEY WR, LOBITZ WC Jr (1953) [Vitiligo with a raised inflammatory border]. AMA Arch Derm Syphilol 67: 316-320.

123. Michaëlsson G (1968) Vitiligo with raised borders. Report of two cases. Acta Derm Venereol 48: 158-161.

124. Le Poole IC, van den Wijngaard RM, Westerhof W, Das PK (1996) Presence of $T$ cells and macrophages in inflammatory vitiligo skin parallels melanocyte disappearance. Am J Pathol 148: 1219-1228.

125. Yagi H, Tokura Y, Furukawa F, Takigawa M (1997) Vitiligo with raised inflammatory borders: Involvement of $\mathrm{T}$ cell immunity and keratinocytes expressing MHC class II and ICAM-1 molecules. Eur J Dermatol 7: 19-22.

126. Gross A, Tapia FJ, Mosca W, Perez RM, Briceño L, et al. (1987) Mononuclear cell subpopulations and infiltrating lymphocytes in erythema dyschromicum perstans and vitiligo. Histol Histopathol 2: 277-283.

27. Badri AM, Todd PM, Garioch JJ, Gudgeon JE, Stewart DG, et al. (1993) An immunohistological study of cutaneous lymphocytes in vitiligo. J Pathol 170 149-155

128. Abdel-Naser MB, Krüger-Krasagakes S, Krasagakis K, Gollnick H, AbdelFattah A, et al. (1994) Further evidence for involvement of both cell mediated and humoral immunity in generalized vitiligo. Pigment Cell Res 7: 1-8.

129. van den Wijngaard R, Wankowicz-Kalinska A, Le Poole C, Tigges B, Westerho $W$, et al. (2000) Local immune response in skin of generalized vitiligo patients. Destruction of melanocytes is associated with the prominent presence of CLA+ T cells at the perilesional site. Lab Invest 80: 1299-1309.

130.Sanchez-Sosa S, Aguirre-Lombardo M, Jimenez-Brito G, Ruiz-Argüelles A (2013) Immunophenotypic characterization of lymphoid cell infiltrates in vitiligo. Clin Exp Immunol 173: 179-183.

131. Bertolotti A, Boniface K, Vergier B, Mossalayi D, Taieb A, et al. (2014) Type interferon signature in the initiation of the immune response in vitiligo. Pigment Cell Melanoma Res 27: 398-407.

132. Wankowicz-Kalinska A, Le Poole C, van den Wijngaard R, Storkus WJ, Das PK (2003) Melanocyte-specific immune response in melanoma and vitiligo: two faces of the same coin? Pigment Cell Res 16: 254-260.

133. Grimes PE, Ghoneum M, Stockton T, Payne C, Kelly AP, et al. (1986) T cell profiles in vitiligo. J Am Acad Dermatol 14: 196-201.

134. Halder RM, Walters CS, Johnson BA, Chakrabarti SG, Kenney JA Jr (1986) Aberrations in T lymphocytes and natural killer cells in vitiligo: a flow cytometric study. J Am Acad Dermatol 14: 733-737.

135. Nigam PK, Patra PK, Khodiar PK, Gual J (2011) A study of blood CD3+ CD4+, and CD8+ T cell levels and CD4+:CD8+ ratio in vitiligo patients. Indian J Dermatol Venereol Leprol 77: 111

136. Dwivedi M, Laddha NC, Arora P, Marfatia YS, Begum R (2013) Decreased regulatory T-cells and CD4(+)/CD8(+) ratio correlate with disease onset and progression in patients with generalized vitiligo. Pigment Cell Melanoma Res 26: 586-591.

137. Lili Y, Yi W, Ji Y, Yue S, Weimin S, et al. (2012) Global activation of CD8+ cytotoxic $T$ lymphocytes correlates with an impairment in regulatory $T$ cells in patients with generalized vitiligo. PLoS One 7: e37513.

138. Das PK, van den Wijngaard RM, Wankowicz-Kalinska A, Le Poole IC (2001) A symbiotic concept of autoimmunity and tumour immunity: lessons from vitiligo. Trends Immunol 22: 130-136.

139. Fishman P, Merimski O, Baharav E, Shoenfeld Y (1997) Autoantibodies to tyrosinase: the bridge between melanoma and vitiligo. Cancer 79: 1461-1464.

140.Song YH, Connor E, Li Y, Zorovich B, Balducci P, et al. (1994) The role of tyrosinase in autoimmune vitiligo. Lancet 344: 1049-1052.

141.Kemp EH, Gawkrodger DJ, MacNeil S, Watson PF, Weetman AP (1997) Detection of tyrosinase autoantibodies in patients with vitiligo using $35 S$-labeled recombinant human tyrosinase in a radioimmunoassay. J Invest Dermatol 109: 69-73.

142. Palermo B, Campanelli $R$, Garbelli S, Mantovani $S$, Lantelme $E$, et al. (2001) Specific cytotoxic T lymphocyte responses against Melan-A/MART1, 
tyrosinase and gp100 in vitiligo by the use of major histocompatibility complex peptide tetramers: the role of cellular immunity in the etiopathogenesis of vitiligo. J Invest Dermatol 117: 326-332.

143. Kemp EH, Gawkrodger DJ, Watson PF, Weetman AP (1998) Autoantibodies to human melanocyte-specific protein pmel17 in the sera of vitiligo patients: a sensitive and quantitative radioimmunoassay (RIA). Clin Exp Immunol 114: 333-338.

144. Kemp EH, Waterman EA, Gawkrodger DJ, Watson PF, Weetman AP (1998) Autoantibodies to tyrosinase-related protein-1 detected in the sera of vitiligo patients using a quantitative radiobinding assay. $\mathrm{Br} \mathrm{J}$ Dermatol 139: 798-805.

145. Hearing VJ (1999) Biochemical control of melanogenesis and melanosomal organization. J Investig Dermatol Symp Proc 4: 24-28.

146. Pradhan V, Patwardhan M, Thakkar V, Kharkar V, Khopkar U, et al. (2013) Vitiligo patients from India (Mumbai) show differences in clinical, demographic and autoantibody profiles compared to patients in western countries. J Eur Acad Dermatol Venereol 27: 279-286.

147. Hedstrand H, Ekwall O, Olsson MJ, Landgren E, Kemp EH, et al. (2001) The transcription factors SOX 9 and SOX10 are vitiligo autoantigens in autoimmune polyendocrine syndrome type I. J Biol Chem 276: 35390-35395.

148. Harning R, Cui J, Bystryn JC (1991) Relation between the incidence and leve of pigment cell antibodies and disease activity in vitiligo. J Invest Dermatol 97 1078-1080

149. Naughton GK, Reggiardo D, Bystryn JC (1986) Correlation between vitiligo antibodies and extent of depigmentation in vitiligo. J Am Acad Dermatol 15 978-981.

150. Pamer E, Cresswell P (1998) Mechanisms of MHC class l--restricted antigen processing. Annu Rev Immunol 16: 323-358.

151. Casp CB, She JX, McCormack WT (2003) Genes of the LMP/TAP cluster are associated with the human autoimmune disease vitiligo. Genes Immun 4: 492-499.

152. Ulianich L, Terrazzano G, Annunziatella M, Ruggiero G, Beguinot F, et al. (2011) ER stress impairs MHC Class I surface expression and increases susceptibility of thyroid cells to NK-mediated cytotoxicity. Biochim Biophys Acta 1812: 431-438.

153. Nieland TJ, Tan MC, Monne-van Muijen M, Koning F, Kruisbeek AM, et al. (1996) Isolation of an immunodominant viral peptide that is endogenously bound to the stress protein GP96/GRP94. Proc Natl Acad Sci U S A 93:61356139 .

154. Lammert E, Arnold D, Nijenhuis M, Momburg F, Hämmerling GJ, et al. (1997) The endoplasmic reticulum-resident stress protein gp96 binds peptides translocated by TAP. Eur J Immunol 27: 923-927.

155. Spee P, Neefjes J (1997) TAP-translocated peptides specifically bind proteins in the endoplasmic reticulum, including gp96, protein disulfide isomerase and calreticulin. Eur J Immunol 27: 2441-2449.

156. Nicchitta CV (1998) Biochemical, cell biological and immunological issues surrounding the endoplasmic reticulum chaperone GRP94/gp96. Curr Opin Immunol 10: 103-109.

157.Degen E, Cohen-Doyle MF, Williams DB (1992) Efficient dissociation of the p88 chaperone from major histocompatibility complex class I molecules requires both beta 2-microglobulin and peptide. J Exp Med 175: 1653-1661.

158. Rajagopalan S, Brenner MB (1994) Calnexin retains unassembled major histocompatibility complex class I free heavy chains in the endoplasmic reticulum. J Exp Med 180: 407-412.

159. Carreno BM, Schreiber KL, McKean DJ, Stroynowski I, Hansen TH (1995) Aglycosylated and phosphatidylinositol-anchored MHC class I molecules are associated with calnexin. Evidence implicating the class I-connecting peptide segment in calnexin association. J Immunol 154: 5173-5180.

160.Nössner E, Parham P (1995) Species-specific differences in chaperone interaction of human and mouse major histocompatibility complex class molecules. J Exp Med 181: 327-337.

161. Parham $P$ (1996) Functions for MHC class I carbohydrates inside and outside the cell. Trends Biochem Sci 21: 427-433.

162. Gleimer M, Parham P (2003) Stress management: MHC class I and class I-like molecules as reporters of cellular stress. Immunity 19: 469-477.

163. Hickman-Miller HD, Hildebrand WH (2004) The immune response under stress: the role of HSP-derived peptides. Trends Immunol 25: 427-433.
164.Wang S, Zhou M, Lin F, Liu D, Hong W, et al. (2014) Interferon- $\hat{l}^{3}$ induces senescence in normal human melanocytes. PLoS One 9: e93232.

165. Natarajan VT, Ganju P, Singh A, Vijayan V, Kirty K, et al. (2014) IFN-î̉ signaling maintains skin pigmentation homeostasis through regulation of melanosome maturation. Proc Natl Acad Sci U S A 111: 2301-2306.

166. Yohn JJ, Critelli M, Lyons MB, Norris DA (1990) Modulation of melanocyte intercellular adhesion molecule-1 by immune cytokines. J Invest Dermatol 95 233-237.

167.al Badri AM, Foulis AK, Todd PM, Gariouch JJ, Gudgeon JE, et al. (1993) Abnormal expression of MHC class II and ICAM-1 by melanocytes in vitiligo. J Pathol 169: 203-206.

168. Gupta S, Gollapudi S (2006) Molecular mechanisms of TNF-alpha-induced apoptosis in naïve and memory T cell subsets. Autoimmun Rev 5: 264-268.

169.Alghamdi KM, Khurrum H, Taieb A, Ezzedine K (2012) Treatment of generalized vitiligo with anti-TNF-Î士 Agents. J Drugs Dermatol 11: 534-539.

170. Tschopp J, Martinon F, Burns K (2003) NALPs: a novel protein family involved in inflammation. Nat Rev Mol Cell Biol 4: 95-104.

171. Martinon F, Gaide O, Pétrilli V, Mayor A, Tschopp J (2007) NALP inflammasomes: a central role in innate immunity. Semin Immunopathol 29: 213-229.

172. Dwivedi M, Laddha NC, Mansuri MS, Marfatia YS, Begum R (2013) Association of NLRP1 genetic variants and mRNA overexpression with generalized vitiligo and disease activity in a Gujarat population. Br J Dermatol 169: 1114-1125.

173. Bassiouny DA, Shaker O (2011) Role of interleukin-17 in the pathogenesis of vitiligo. Clin Exp Dermatol 36: 292-297.

174.Zhao L, Ackerman SL (2006) Endoplasmic reticulum stress in health and disease. Curr Opin Cell Biol 18: 444-452.

175. Lepe V, Moncada B, Castanedo-Cazares JP, Torres-Alvarez MB, Ortiz CA et al. (2003) A double-blind randomized trial of $0.1 \%$ tacrolimus vs $0.05 \%$ clobetasol for the treatment of childhood vitiligo. Arch Dermatol 139: 581-585.

176. Harding HP, Zhang Y, Zeng H, Novoa I, Lu PD, et al. (2003) An integrated stress response regulates amino acid metabolism and resistance to oxidative stress. Mol Cell 11: 619-633.

177.Tu BP, Weissman JS (2004) Oxidative protein folding in eukaryotes: mechanisms and consequences. J Cell Biol 164: 341-346.

178. Sevier CS, Qu H, Heldman N, Gross E, Fass D, et al. (2007) Modulation of cellular disulfide-bond formation and the ER redox environment by feedback regulation of Ero1. Cell 129: 333-344.

179.Deniaud A, Sharaf el dein O, Maillier E, Poncet D, Kroemer G, et al. (2008) Endoplasmic reticulum stress induces calcium-dependent permeability transition, mitochondrial outer membrane permeabilization and apoptosis. Oncogene 27: 285-299

180. Malhotra JD, Miao H, Zhang K, Wolfson A, Pennathur S, et al. (2008) Antioxidants reduce endoplasmic reticulum stress and improve protein secretion. Proc Natl Acad Sci U S A 105: 18525-18530.

181. Morito D, Nagata K (2012) ER Stress Proteins in Autoimmune and Inflammatory Diseases. Front Immunol 3: 48.

182. Yoshida Y, Murakami A, Iwai K, Tanaka K (2007) A neural-specific F-box protein Fbs1 functions as a chaperone suppressing glycoprotein aggregation J Biol Chem 282: 7137-7144.

183.Zhang K, Kaufman RJ (2008) From endoplasmic-reticulum stress to the inflammatory response. Nature 454: 455-462.

184. Corrigall VM, Bodman-Smith MD, Fife MS, Canas B, Myers LK, et al. (2001) The human endoplasmic reticulum molecular chaperone $\mathrm{BiP}$ is an autoantigen for rheumatoid arthritis and prevents the induction of experimental arthritis. $J$ Immunol 166: 1492-1498.

185. Gordon TP, Bolstad Al, Rischmueller M, Jonsson R, Waterman SA (2001) Autoantibodies in primary Sjögren's syndrome: new insights into mechanisms of autoantibody diversification and disease pathogenesis. Autoimmunity 34 123-132.

186. Park YJ, Yoo SA, Kim WU (2014) Role of endoplasmic reticulum stress in rheumatoid arthritis pathogenesis. J Korean Med Sci 29: 2-11.

187. Xue X, Piao JH, Nakajima A, Sakon-Komazawa S, Kojima Y, et al. (2005) Tumor necrosis factor alpha (TNFalpha) induces the unfolded protein response 
(UPR) in a reactive oxygen species (ROS)-dependent fashion, and the UPR counteracts ROS accumulation by TNFalpha. J Biol Chem 280: 33917-33925

188. Eizirik DL, Cardozo AK, Cnop M (2008) The role for endoplasmic reticulum stress in diabetes mellitus. Endocr Rev 29: 42-61.

189. Laybutt DR, Preston AM, Akerfeldt MC, Kench JG, Busch AK, et al. (2007) Endoplasmic reticulum stress contributes to beta cell apoptosis in type 2 diabetes. Diabetologia 50: 752-763.

190.Zhang K, Wong HN, Song B, Miller CN, Scheuner D, et al. (2005) The unfolded protein response sensor IRE1alpha is required at 2 distinct steps in B cell lymphopoiesis. J Clin Invest 115: 268-281.

191. Shaffer AL, Shapiro-Shelef M, Iwakoshi NN, Lee AH, Qian SB, et al. (2004) XBP1, downstream of Blimp-1, expands the secretory apparatus and other organelles, and increases protein synthesis in plasma cell differentiation. Immunity 21: 81-93.

192. Niu H, Ye BH, Dalla-Favera R (1998) Antigen receptor signaling induces MAP kinase-mediated phosphorylation and degradation of the BCL-6 transcription factor. Genes Dev 12: 1953-1961.

193. Lin KI, Angelin-Duclos C, Kuo TC, Calame K (2002) Blimp-1-dependent repression of Pax -5 is required for differentiation of $B$ cells to immunoglobulin M-secreting plasma cells. Mol Cell Biol 22: 4771-4780.

194. Reimold AM, Ponath PD, Li YS, Hardy RR, David CS, et al. (1996) Transcription factor B cell lineage-specific activator protein regulates the gene for human X-box binding protein 1. J Exp Med 183: 393-401.

195. Iwakoshi NN, Pypaert M, Glimcher LH (2007) The transcription factor XBP-1 is essential for the development and survival of dendritic cells. J Exp Med 204: 2267-2275

196. Goodall JC, Wu C, Zhang Y, McNeill L, Ellis L, et al. (2010) Endoplasmic reticulum stress-induced transcription factor, $\mathrm{CHOP}$, is crucial for dendritic cell IL-23 expression. Proc Natl Acad Sci U S A 107: 17698-17703.

197. Cullinan SB, Diehl JA (2004) PERK-dependent activation of Nrf2 contributes to redox homeostasis and cell survival following endoplasmic reticulum stress. J Biol Chem 279: 20108-20117.

198. Cullinan SB, Diehl JA (2004) PERK-dependent activation of Nrf2 contributes to redoX homeostasis and cell survival following endoplasmic reticulum stress. Journal of Biological Chemistry 279: 20108-20117.

199. Hu P, Han Z, Couvillon AD, Kaufman RJ, Exton JH (2006) Autocrine tumor necrosis factor alpha links endoplasmic reticulum stress to the membrane death receptor pathway through IRE1alpha-mediated NF-kappaB activation and down-regulation of TRAF2 expression. Mol Cell Biol 26: 3071-3084.

200. Davis RJ (2000) Signal transduction by the JNK group of MAP kinases. Cell 103: 239-252.

201. Yamazaki H, Hiramatsu N, Hayakawa K, Tagawa Y, Okamura M, et al. (2009) Activation of the Akt-NF-kappaB pathway by subtilase cytotoxin through the ATF6 branch of the unfolded protein response. J Immunol 183: 1480-1487.

202.Delépine M, Nicolino M, Barrett T, Golamaully M, Lathrop GM, et al. (2000) EIF2AK3, encoding translation initiation factor 2-alpha kinase 3 , is mutated in patients with Wolcott-Rallison syndrome. Nat Genet 25: 406-409.

203. Wang Q, Zhang H, Zhao B, Fei H (2009) IL-1 beta caused pancreatic beta-cells apoptosis is mediated in part by endoplasmic reticulum stress via the induction of endoplasmic reticulum $\mathrm{Ca} 2+$ release through the $\mathrm{c}$-Jun $\mathrm{N}$-terminal kinase pathway. Mol Cell Biochem 324: 183-190.

204. Cardozo AK, Ortis F, Storling J, Feng YM, Rasschaert J, et al. (2005) Cytokines downregulate the sarcoendoplasmic reticulum pump Ca2+ ATPase $2 \mathrm{~b}$ and deplete endoplasmic reticulum $\mathrm{Ca} 2+$, leading to induction of endoplasmic reticulum stress in pancreatic beta-cells. Diabetes 54: 452-461.

205. Laddha NC, Dwivedi M, Mansuri MS, Singh M, Patel HH, et al. (2014) Association of Neuropeptide $Y$ (NPY), Interleukin-1 $\beta$ (IL1B) genetic variants and correlation of IL1B transcript levels with Vitiligo susceptibility. PLoS ONE 9: e107020.

206. Oyadomari S, Mori M (2004) Roles of CHOP/GADD153 in endoplasmic reticulum stress. Cell Death Differ 11: 381-389.

207. Messmer UK, Brüne B (1996) Nitric oxide-induced apoptosis: p53-dependent and p53-independent signalling pathways. Biochem J 319: 299-305.

208. Viner RI, Ferrington DA, Williams TD, Bigelow DJ, Schöneich C (1999) Protein modification during biological aging: selective tyrosine nitration of the
SERCA2a isoform of the sarcoplasmic reticulum Ca2+-ATPase in skeletal muscle. Biochem J 340: 657-669.

209. Oyadomari S, Takeda K, Takiguchi M, Gotoh T, Matsumoto M, et al. (2001) Nitric oxide-induced apoptosis in pancreatic beta cells is mediated by the endoplasmic reticulum stress pathway. Proc Natl Acad Sci U S A 98: 1084510850

210.Kolls JK, Lindén A (2004) Interleukin-17 family members and inflammation Immunity 21: 467-476

211. Moretti S, Fabbri P, Baroni G, Berti S, Bani D, et al. (2009) Keratinocyte dysfunction in vitiligo epidermis: cytokine microenvironment and correlation to keratinocyte apoptosis. Histol Histopathol 24: 849-857.

212. Kumar A, Takada Y, Boriek AM, Aggarwal BB (2004) Nuclear factor-kappaB its role in health and disease. $\mathrm{J} \mathrm{Mol} \mathrm{Med} \mathrm{(Berl)} \mathrm{82:} \mathrm{434-448.}$

213. Krause KH, Michalak M (1997) Calreticulin. Cell 88: 439-443.

214. Guermonprez P, Saveanu L, Kleijmeer M, Davoust J, Van Endert P, et al. (2003) ER-phagosome fusion defines an MHC class I cross-presentation compartment in dendritic cells. Nature 425: 397-402.

215. Rutkevich LA, Williams DB (2011) Participation of lectin chaperones and thio oxidoreductases in protein folding within the endoplasmic reticulum. Curr Opin Cell Biol 23: 157-166.

216. Frasconi M, Chichiarelli S, Gaucci E, Mazzei F, Grillo C, et al. (2012) Interaction of ERp57 with calreticulin: Analysis of complex formation and effects of vancomycin. Biophys Chem 160: 46-53.

217. Cho JH, Homma KJ, Kanegasaki S, Natori S (2001) Activation of human monocyte cell line U937 via cell surface calreticulin. Cell Stress Chaperones 6: $148-152$.

218. Gardai SJ, McPhillips KA, Frasch SC, Janssen WJ, Starefeldt A, et al. (2005) Cell-surface calreticulin initiates clearance of viable or apoptotic cells through trans-activation of LRP on the phagocyte. Cell 123: 321-334

219.Porcellini S, Traggiai E, Schenk U, Ferrera D, Matteoli M, et al. (2006) Regulation of peripheral T cell activation by calreticulin. J Exp Med 203: 461471.

220. Wang S1, Kaufman RJ (2012) The impact of the unfolded protein response on human disease. J Cell Biol 197: 857-867.

221.Donnelly S, Roake W, Brown S, Young P, Naik H, et al. (2006) Impaired recognition of apoptotic neutrophils by the $\mathrm{C} 1 \mathrm{q} /$ calreticulin and CD91 pathway in systemic lupus erythematosus. Arthritis Rheum 54: 1543-1556.

222. Fogal V, Zhang L, Krajewski S, Ruoslahti E (2008) Mitochondrial/cell-surface protein $\mathrm{p} 32 / \mathrm{gC} 1 \mathrm{qR}$ as a molecular target in tumor cells and tumor stroma. Cancer Res 68: 7210-7218.

223. Del Cid N, Jeffery E, Rizvi SM, Stamper E, Peters LR, et al. (2010) Modes of calreticulin recruitment to the major histocompatibility complex class assembly pathway. J Biol Chem 285: 4520-4535.

224.Zhang Y, Liu L, Jin L, Yi X, Dang E, et al. (2014) Oxidative stress-induced calreticulin expression and translocation: new insights into the destruction of melanocytes. J Invest Dermatol 134: 183-191.

225. Panaretakis T, Laane E, Pokrovskaja K, Björklund AC, Moustakas A, et al. (2005) Doxorubicin requires the sequential activation of caspase-2, protein kinase Cdelta, and C-Jun NH2-terminal kinase to induce apoptosis. Mol Bio Cell 16: 3821-3831.

226. Obeid M, Tesniere A, Panaretakis T, Tufi $R$, Joza N, et al. (2007) Ectocalreticulin in immunogenic chemotherapy. Immunol Rev 220: 22-34.

227.Perez CA, Fu A, Onishko H, Hallahan DE, Geng L (2009) Radiation induces an antitumour immune response to mouse melanoma. Int J Radiat Biol 85 1126-1136.

228. Mosca PJ, Robertson GP (2011) Augmentation of tumor-specific immunity by upregulation of apoptotic melanoma cell calreticulin expression. Cancer Bio Ther 11: $581-583$

229. Chao MP, Jaiswal S, Weissman-Tsukamoto R, Alizadeh AA, Gentles AJ, et al. (2010) Calreticulin is the dominant pro-phagocytic signal on multiple human cancers and is counterbalanced by CD47. Sci Transl Med 2: 63ra94.

230. Ihara Y, Urata Y, Goto S, Kondo T (2006) Role of calreticulin in the sensitivity of myocardiac $\mathrm{H} 9 \mathrm{c} 2$ cells to oxidative stress caused by hydrogen peroxide. Am J Physiol Cell Physiol 290: C208-221. 
231. Welch WJ (1993) Heat shock proteins functioning as molecular chaperones: their roles in normal and stressed cells. Philos Trans R Soc Lond B Biol Sci 339: 327-333.

232. Jansen G, Määttänen P, Denisov AY, Scarffe L, Schade B, et al. (2012) An interaction map of endoplasmic reticulum chaperones and foldases. Mol Cell Proteomics 11: 710-723.

233. Gardner BM, Pincus D, Gotthardt K, Gallagher CM, Walter P (2013) Endoplasmic reticulum stress sensing in the unfolded protein response. Cold Spring Harb Perspect Biol 5: a013169.

234. Vega VL, Rodríguez-Silva M, Frey T, Gehrmann M, Diaz JC, et al. (2008) Hsp70 translocates into the plasma membrane after stress and is released into the extracellular environment in a membrane-associated form that activates macrophages. J Immunol 180: 4299-4307.

235. Chi A, Valencia JC, Hu ZZ, Watabe H, Yamaguchi H, et al. (2006) Proteomic and bioinformatic characterization of the biogenesis and function of melanosomes. J Proteome Res 5: 3135-3144.

236. Mambula SS, Calderwood SK (2006) Heat shock protein 70 is secreted from tumor cells by a nonclassical pathway involving lysosomal endosomes. J Immunol 177: 7849-7857.

237. Johnson JD, Fleshner M (2006) Releasing signals, secretory pathways, and immune function of endogenous extracellular heat shock protein 72 . J Leukoc Biol 79: 425-434

238. Nicchitta CV (2003) Re-evaluating the role of heat-shock protein-peptide interactions in tumour immunity. Nat Rev Immunol 3: 427-432.

239. Multhoff G (2009) Activation of natural killer cells by heat shock protein 70 . In J Hyperthermia 25:169-175.

240. Kammerer R, Stober D, Riedl P, Oehninger C, Schirmbeck R, et al. (2002) Noncovalent association with stress protein facilitates cross-priming of CD8+ $\mathrm{T}$ cells to tumor cell antigens by dendritic cells. J Immunol 168: 108-117.

241. Millar DG, Garza KM, Odermatt B, Elford AR, Ono N, et al. (2003) Hsp70 promotes antigen-presenting cell function and converts $\mathrm{T}$-cell tolerance to autoimmunity in vivo. Nat Med 9: 1469-1476.

242. Mosenson JA, Zloza A, Klarquist J, Barfuss AJ, Guevara-Patino JA, et al. (2012) HSP70i is a critical component of the immune response leading to vitiligo. Pigment Cell Melanoma Res 25: 88-98.

243. Mosenson JA, Zloza A, Nieland JD, Garrett-Mayer E, Eby JM, et al. (2013) Mutant HSP70 reverses autoimmune depigmentation in vitiligo. Sci Transl Med 5: 174ra28.

244. Mosenson JA, Eby JM, Hernandez C, Le Poole IC (2013) A central role for inducible heat-shock protein 70 in autoimmune vitiligo. Exp Dermatol 22: 566569.

245. Jin Y, Birlea SA, Fain PR, Gowan K, Riccardi SL, et al. (2011) Genomewide analysis identifies a quantitative trait locus in the MHC class II region associated with generalized vitiligo age of onset. J Invest Dermatol 131: 13081312.

246. Jin Y, Birlea SA, Fain PR, Ferrara TM, Ben S, et al. (2012) Genome-wide association analyses identify 13 new susceptibility loci for generalized vitiligo. Nat Genet 44: 676-680.

247. Jin Y, Birlea SA, Fain PR, Gowan K, Riccardi SL, et al. (2010) Variant of TYR and autoimmunity susceptibility loci in generalized vitiligo. N Engl J Med 362: 1686-1697.

248. Acar E, Bozkurt G, Gorgulu A (2012) Polymorphisms in the Melanocortin-1 Receptor (Mc1R) Gene in Vitiligo. Balkan Medical Journal 29: 26.

249. Na GY, Lee KH, Kim MK, Lee SJ, Kim DW, et al. (2003) Polymorphisms in the melanocortin-1 receptor (MC1R) and agouti signaling protein (ASIP) genes in Korean vitiligo patients. Pigment Cell Res 16: 383-387.

250. Birlea SA, Ahmad FJ, Uddin RM, Ahmad S, Pal SS, et al. (2013) Association of generalized vitiligo with MHC class II loci in patients from the Indian subcontinent. J Invest Dermatol 133: 1369-1372.

251.Dwivedi M, Laddha NC, Imran M, Shah BJ, Begum R (2011) Cytotoxic T-lymphocyte-associated antigen-4 (CTLA-4) in isolated vitiligo: a genotypephenotype correlation. Pigment Cell Melanoma Res 24: 737-740.

252. Yasar A, Gunduz K, Onur E, Calkan M (2012) Serum homocysteine, vitamin $\mathrm{B} 12$, folic acid levels and methylenetetrahydrofolate reductase (MTHFR) gene polymorphism in vitiligo. Dis Markers 33: 85-89.
253. Spritz RA (2012) Six decades of vitiligo genetics: genome-wide studies provide insights into autoimmune pathogenesis. J Invest Dermatol 132: 268-273.

254. Bulut H, Pehlivan M, Alper S, Tomatir AG, Onay H, et al. (2011) Lack of association between catalase gene polymorphism (T/C exon 9) and susceptibility to vitiligo in a Turkish population. Genet Mol Res 10: 4126-4132.

255. Mansuri MS, Singh M, Dwivedi M, Laddha NC, Marfatia YS, et al. (2014) miRNA profiling revealed differentially expressed miRNA signatures from skin of non-segmental Vitiligo. Brit J Dermatol (In press).

256. Haskins K, Bradley B, Powers K, Fadok V, Flores S, et al. (2003) Oxidative stress in type 1 diabetes. Ann N Y Acad Sci 1005: 43-54.

257. Tersey SA, Nishiki Y, Templin AT, Cabrera SM, Stull ND, et al. (2012) Islet $\hat{~}^{2}$ cell endoplasmic reticulum stress precedes the onset of type 1 diabetes in the nonobese diabetic mouse model. Diabetes 61: 818-827.

258. Knip M, Siljander H (2008) Autoimmune mechanisms in type 1 diabetes. Autoimmun Rev 7: 550-557.

259. Folli F, Corradi D, Fanti P, Davalli A, Paez A, et al. (2011) The role of oxidative stress in the pathogenesis of type 2 diabetes mellitus micro- and macrovascular complications: avenues for a mechanistic-based therapeutic approach. Curr Diabetes Rev 7: 313-324.

260.Back SH, Kaufman RJ (2012) Endoplasmic reticulum stress and type 2 diabetes. Annu Rev Biochem 81: 767-793.

261. Sundar Rajan S, Srinivasan V, Balasubramanyam M, Tatu U (2007) Endoplasmic reticulum (ER) stress \& diabetes. Indian J Med Res 125: 411424.

262. Markesbery WR (1997) Oxidative stress hypothesis in Alzheimer's disease Free Radic Biol Med 23: 134-147.

263. Salminen A, Kauppinen A, Suuronen T, Kaarniranta K, Ojala J (2009) ER stress in Alzheimer's disease: a novel neuronal trigger for inflammation and Alzheimer's pathology. J Neuroinflammation 26: 6-41.

264. Hitomi J, Katayama T, Eguchi Y, Kudo T, Taniguchi M, et al. (2004) Involvement of caspase-4 in endoplasmic reticulum stress-induced apoptosis and Abeta-induced cell death. J Cell Biol 165: 347-356.

265. Jenner $P$ (2003) Oxidative stress in Parkinson's disease. Ann Neurol 53 Supp 3: S26-36.

266. Hwang O (2013) Role of oxidative stress in Parkinson's disease. Exp Neurobio 22: $11-17$.

267. Omura T, Kaneko M, Okuma Y, Matsubara K, Nomura Y (2013) Endoplasmic reticulum stress and Parkinson's disease: the role of HRD1 in averting apoptosis in neurodegenerative disease. Oxid Med Cell Longev 2013: 239854

268. Wang $H Q$, Takahashi $R$ (2007) Expanding insights on the involvement of endoplasmic reticulum stress in Parkinson's disease. Antioxid Redox Signal 9: 553-561.

269. Noda N, Wakasugi H (2001) Cancer and Oxidative Stress. JMAJ 44: 535-539

270.Sosa V, Moliné T, Somoza R, Paciucci R, Kondoh H, et al. (2013) Oxidative stress and cancer: an overview. Ageing Res Rev 12: 376-390.

271. Moenner M, Pluquet O, Bouchecareilh M, Chevet E (2007) Integrated endoplasmic reticulum stress responses in cancer. Cancer Res 67: 1063110634

272. Bonomini F, Tengattini S, Fabiano A, Bianchi R, Rezzani R (2008) Atherosclerosis and oxidative stress. Histol Histopathol 23: 381-390.

273. Harrison D, Griendling KK, Landmesser U, Hornig B, Drexler H (2003) Role of oxidative stress in atherosclerosis. Am J Cardiol 91: 7A-11A

274. Hotamisligil GS (2010) Endoplasmic reticulum stress and atherosclerosis. Nat Med 16: 396-399.

275. Di Filippo C, Cuzzocrea S, Rossi F, Marfella R, D'Amico M (2006) Oxidative stress as the leading cause of acute myocardial infarction in diabetics. Cardiovasc Drug Rev 24: 77-87.

276. Surekha RH, Srikanth BB, Jharna P, Ramachandra RV, Dayasagar RV, et al. (2007) Oxidative stress and total antioxidant status in myocardial infarction. Singapore Med J 48: 137-142.

277. Glembotski CC (2007) Endoplasmic reticulum stress in the heart. Circ Res 101: $975-984$ 
Citation: Mansuri MS, Singh M, Jadeja SD, Gani AR, Patel R, et al. (2014) Could ER Stress Be A Major Link Between Oxidative Stress And Autoimmunity In Vitiligo?. Pigmentary Disorders 1: 123. doi:10.4172/2376-0427.1000123

Page 14 of 14

278. Tsutsui H, Kinugawa S, Matsushima S (2011) Oxidative stress and heart failure. Am J Physiol Heart Circ Physiol 301: H2181-2190.

279. Minamino T, Kitakaze M (2010) ER stress in cardiovascular disease. J Mo Cell Cardiol 48: 1105-1110.

280. Almenier HA, Al Menshawy HH, Maher MM, Al Gamal S (2012) Oxidative stress and inflammatory bowel disease. Front Biosci (Elite Ed) 4: 1335-1344.
281. Niederreiter L, Kaser A (2011) Endoplasmic reticulum stress and inflammatory bowel disease. Acta Gastroenterol Belg 74: 330-333.

282. Wen Z, Fiocchi C (2004) Inflammatory bowel disease: autoimmune or immunemediated pathogenesis? Clin Dev Immunol 11: 195-204. 